\title{
Targeting Enteropeptidase with Reversible Covalent Inhibitors To Achieve Metabolic Benefits
}

\author{
Weimei Sun, Xuqing Zhang, Maxwell D. Cummings, Kamal Albarazanji, Jiejun Wu, \\ Mina Wang, Richard Alexander, Bin Zhu, YueMei Zhang, James Leonard, James Lanter, \\ and James Lenhard
}

DPDS Discovery Technology and Molecular Pharmacology, Spring House, Pennsylvania (W.S., M.W., R.A.); DPDS Analytical Sciences, La Jolla, California (J.W.); Discovery Chemistry, Spring House, Pennsylvania (X.Z., M.D.C., B.Z., Y.Z., J.La.); CVM Discovery, Spring House, Pennsylvania (K.A., J.Leo., J.Len.); and Janssen Research \& Development, LLC, Spring House, Pennsylvania

Received July 14, 2020; accepted September 8, 2020

\begin{abstract}
Inhibition of the serine protease enteropeptidase (EP) opens a new avenue to the discovery of chemotherapeutics for the treatment of metabolic diseases. Camostat has been used clinically for treating chronic pancreatitis in Japan; however, the mechanistic basis of the observed clinical efficacy has not been fully elucidated. We demonstrate that camostat is a potent reversible covalent inhibitor of EP, with an inhibition potency $\left(k_{\text {inact }} / \mathrm{K}_{\mathrm{l}}\right)$ of $1.5 \times 10^{4} \mathrm{M}^{-1} \mathrm{~s}^{-1}$. High-resolution liquid chromatography-mass spectrometry (LC-MS) showed addition of 161.6 Da to EP after the reaction with camostat, consistent with insertion of the carboxyphenylguanidine moiety of camostat. Covalent inhibition of EP by camostat is reversible, with an enzyme reactivation half-life of 14.3 hours. Formation of a covalent adduct was further supported by a crystal structure resolved to $2.19 \AA$, showing modification of the catalytic serine of EP by a close analog of camostat, leading to formation of the carboxyphenylguanidine acyl enzyme identical to that expected for the reaction with camostat. Of particular note, minor structural modifications of camostat led to changes in the mechanism of inhibition. We observed from other studies that
\end{abstract}

\section{Introduction}

Enteropeptidase (EP, EC. 3.4.21.9) is a serine protease exclusively localized to the apical membrane of the proximal small intestine (Yuan et al., 1998; Imamura and Kitamoto, 2003). The initiation of intestinal nutrient digestion occurs in the lumen of the upper duodenum through the proteolytic processing of trypsinogen to catalytically active trypsin by EP (Light and Janska, 1989; Kitamoto et al., 1995; Zheng et al., 2009). This initiates a cascade of events leading to zymogen

This paper received no external funding.

This work was previously presented as an abstract at the following meeting: Zhang X, Sun W, Lanter J, Zhu B, Cummings MD, Wu J, Albarazanji K, Wang M, Lenhard J, and Leonard J. Targeting enteropeptidase by reversible covalent inhibitors. Abstracts of Papers, 259th ACS National Meeting \& Exposition; 2020 March 22-26; Philadelphia, PA. MEDI-0148.

https://doi.org/10.1124/jpet.120.000219. sustained inhibition of EP is required to effect a reduction in cumulative food intake and body weight, with concomitant improved blood glucose levels in obese and diabetic leptindeficient mice. Thus, the structure-activity relationship needs to be driven by not only the inhibition potency but also the mechanistic and kinetic characterization. Our findings support EP as a target for the treatment of metabolic diseases and demonstrate that reversible covalent EP inhibitors show clinically relevant efficacy.

\section{SIGNIFICANCE STATEMENT}

Interest in targeted covalent drugs has expanded in recent years, particularly so for kinase targets, but also more broadly. This study demonstrates that reversible covalent inhibition of the serine protease enteropeptidase is a therapeutically viable approach to the treatment of metabolic diseases and that mechanistic details of inhibition are relevant to clinical efficacy. Our mechanistic and kinetic studies outline a framework for detailed inhibitor characterization that is proving essential in guiding discovery efforts in this area.

ABBREVIATIONS: br, broad; $d$, doublet; EP, enteropeptidase; J, coupling constant; $\mathrm{m}$, multiplet; NA, $\beta$-naphthylamine; ob/ob mice, leptindeficient mice; s, singlet; SAR, structure-activity relationship; $t_{1 / 2}$, half-life. 
a disulfide bond. The light chain comprises a trypsin-like serine protease domain with a typical Asp-His-Ser catalytic triad (Light and Janska, 1989; Zheng et al., 2009). The structural basis for the observed classic trypsin-like substrate specificity at P1 (Schechter and Berger, 1967) as well as the unusual P2-P4 Asp-Asp-Asp recognition sequence has been thoroughly discussed (Lu et al., 1999). The protease domain of EP shows high structural similarity with and $>40 \%$ sequence identity to related proteases, including matriptase, plasma kallikrein, hepsin, FXIa, epitheliasin, and prostasin. In addition to the N-terminal transmembrane domain that serves to anchor EP in the brush border, the heavy chain includes several additional structural domains of varying function (Kitamoto et al., 1994; Zheng et al., 2009).

Camostat (Fig. 1) was reported to inhibit trypsin-like serine proteases. Diabetic rats treated with camostat showed significant reduction in blood glucose and body weight as well as improved insulin resistance (Ito et al., 2007). Camostat is clinically approved for treating pancreatitis and reflux esophagitis in Japan. Patients treated with camostat for pancreatitis for 8 years showed significantly lower incidence of diabetes (Kitagawa and Hayakawa, 2007; Bronze-da-Rocha and Santos-Silva, 2018; Ramsey et al., 2019). However, the pharmacological mechanism underlying the observed clinical efficacy has not been fully elucidated.

We observed that camostat is a potent inhibitor of EP. Our study establishes EP as a viable therapeutic target for obesity and diabetes based on pharmacologic results observed with leptin-deficient mice ( $o b / o b$ mice) treated with camostat and camostat-like inhibitors. Additional evidence has recently emerged illustrating that inhibition of EP can lead to therapeutically useful metabolic effects in animal models (Sasaki et al., 2019; Yashiro et al., 2019).

To leverage the established safety profile of this clinically approved molecule, an extensive chemical design effort around the camostat scaffold was undertaken to identify new EP inhibitors with increased inhibition potency and enhanced pharmacological properties. Our approach is to target protein digestion in the duodenum by inhibiting EP locally. This gastrointestinal tract-restricted modality offers both the challenge of durably inhibiting EP and the opportunity to mitigate potential off-target effects by limiting drug exposure to the alimentary organs.

The mechanism of EP inhibition by camostat was thoroughly characterized to establish a benchmark and outline a framework for kinetic and mechanistic characterization aimed at reliable and pharmacologically relevant ranking of new inhibitors. The results of our structure-activity relationship (SAR) and pharmacological studies will be reported in separate publications. In the present work, we focus on kinetic and mechanistic characterization of EP inhibition by camostat as well as new inhibitors we are evaluating. Our explorations have yielded a variety of EP inhibitors with differentiated mechanisms. It is clearly demonstrated that detailed in vitro biochemical characterization of inhibition kinetics and mechanism is critical to SAR generation and comprehension, which in turn is essential in the selection of lead compounds most likely to show the desired pharmacological effects.

\section{Materials and Methods}

Recombinant full-length human EP, expressed and purified from CHO cells, was purchased from PeproTech (catalog number 450-48C).

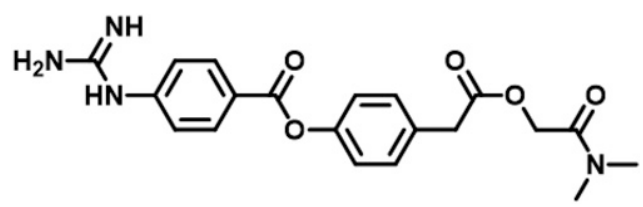

Fig. 1. Molecular structure of camostat.

Recombinant light chain of bovine EP (residues 801-1035), expressed and purified from Escherichia coli, was purchased from R\&D Systems (catalog number 4139-SE). This form of the light chain of EP contains the C-terminal fragment of the heavy chain, Cys788-Lys800 with an N-terminal Ala, and Ile801-His1035 of the light chain. Peptide GlyAsp-Asp-Asp-Asp-Lys- $\beta$-naphthylamide, purity greater than $95 \%$ by high performance liquid chromatography (HPLC) analysis, was purchased from Sigma (catalog number G5261); the powder was dissolved in DMSO and stored at $-20^{\circ} \mathrm{C} . \beta$-Naphthylamine (NA, catalog number 31618), camostat mesylate (catalog number SML0057), Triton X-100 (catalog number 93443), and urea (catalog number 1084880250) were all purchased from Sigma-Aldrich. NaCl solution (5 $\mathrm{M}$; catalog number $\mathrm{S} 0250$ ) and $1 \mathrm{M}$ Tris- $\mathrm{HCl}$ at $\mathrm{pH} 7.4$ (catalog number T1074) were purchased from Teknova. LC-MS-grade B\&J Brand water (catalog number LC365-4), water with $0.1 \%$ formic acid (catalog number LC452-1), and acetonitrile with $0.1 \%$ formic acid (catalog number LC441-1) were purchased from Honeywell International Inc. (Muskegon, MI). Anhydrous DMSO was purchased from EMD Millipore Corporation (catalog number MX1457-7). The 384-well nonbinding surface black plates, used for biochemical assays, were purchased from Perkin Elmer (catalog number 6007279). A Labcyte Echo 550 was used for nanoliter compound transfers, an Infinite M1000 plate reader (Tecan Group) was used for kinetic reading of fluorescence intensity, and an Eppendorf centrifuge 5810 was used to spin assay plates to ensure thorough mixing of solutions and to remove bubbles generated from pipetting. Micro Bio-SpinTM P-6 Gel columns (catalog number 7326200) were purchased from Bio-Rad Laboratories.

In Vitro Biochemical Assay. Recombinant full-length human $\mathrm{EP}$ was used in the biochemical assay, with the quenched fluorescently labeled peptide Gly-Asp-Asp-Asp-Asp-Lys- $\beta$-naphthylamide as substrate in assay buffer [50 mM Tris-HCl $(\mathrm{pH} 7.4), 200 \mathrm{mM} \mathrm{NaCl}$, $0.01 \%$ Triton X-100]. Assay buffer was prepared from purchased stock solutions and was diluted with LC-MS-grade water. Progress curves of protease activity were measured by monitoring the fluorescence intensity of the cleavage product NA at excitation and emission wavelengths of 340 and $410 \mathrm{~nm}$, respectively.

Inhibition of EP. Concentration-dependent inhibition studies involved mixing equal volumes of $600 \mu \mathrm{M}$ substrate and $2.5 \mathrm{nM}$ EP solutions. Compounds were dissolved to $10 \mathrm{mM}$ in DMSO immediately prior to use in inhibition studies, and 2-fold serial dilutions from $10 \mathrm{mM}$ were made with DMSO, for a total of 11 inhibitor concentrations; a DMSO control (no inhibitor) was also included. Inhibitor solutions were transferred to assay plates with an Echo acoustic liquid dispenser. Reaction was initiated by addition of the enzyme solution to the mixture of substrate and compound. Reaction progress curve data were collected continuously at 1 -minute intervals for 60 minutes. The observed inactivation rate constant $\left(k_{\text {obs }}\right)$ was derived by fitting the reaction progress curve to eq. 1.

$$
\mathrm{Y}_{\mathrm{T}}=v_{\mathrm{s}} \mathrm{t}+\frac{v_{i}-v_{s}}{k_{\mathrm{obs}}}\left(1-\mathrm{e}^{-k_{\mathrm{obs}} \mathrm{t}}\right)+\mathrm{Y}_{0}
$$

$\mathrm{Y}_{\mathrm{T}}$ is the detection signal of the reaction at time t; $v_{i}$ and $v_{s}$ are the initial and the steady-state velocities of the reaction, respectively; and $\mathrm{t}$ is the reaction time. $\mathrm{Y}_{0}$ is the background signal at $\mathrm{t}=0$.

The derived inactivation rate constant $\left(k_{\text {obs }}\right)$ is dependent on inhibitor concentration. A linear dependence indicates a one-step mechanism (Scheme A), with the slope of the linear fit equivalent to the second-order rate constant of compound binding $\left(\mathrm{k}_{1}\right)$, which is used 
A

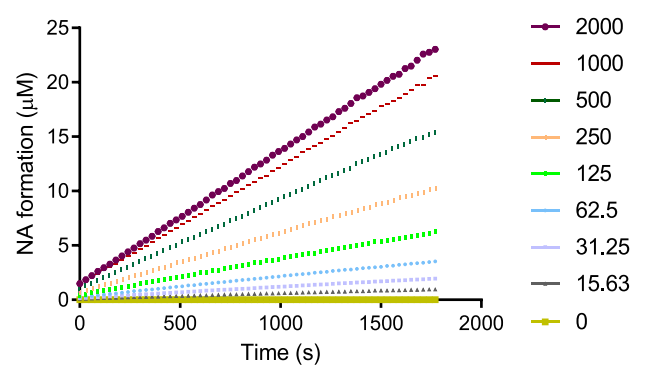

B

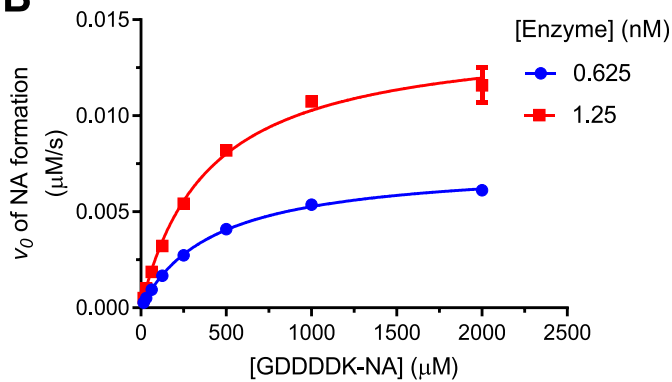

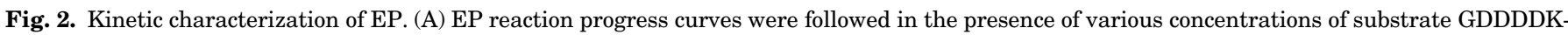

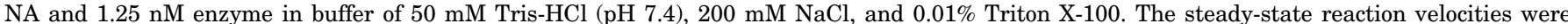

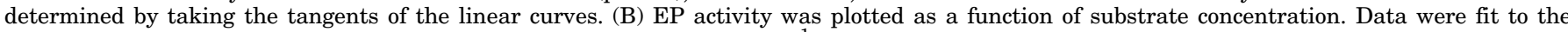

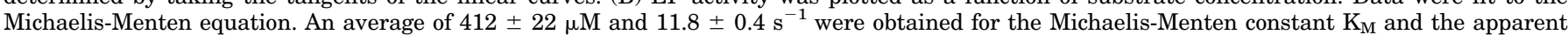
turnover number $k_{c a t}$, respectively. Data are the averages of two independent experiments.

to represent the compound inhibition potency $\left(k_{\text {inact }} / \mathrm{K}_{\mathrm{I}}\right)$. Alternatively, a hyperbolic fit of $k_{\text {obs }}$ versus [I] indicates a two-step binding mechanism (Scheme B), wherein the plateau of the curve is the forward rate constant of the isomerization step $\left(k_{3}\right)$, and $\mathrm{K}_{\mathrm{I}}$ is the inhibitor concentration that gives half-maximal inactivation. Inhibition potency $\left(k_{\text {inact }} / \mathrm{K}_{\mathrm{I}}\right)$ is reported as the ratio $k_{3} / \mathrm{K}_{\mathrm{I}}$, with substrate competition corrected for by the term $\left(1+[\mathrm{S}] / \mathrm{K}_{\mathrm{M}}\right)$.

Kinetic Data Analysis. Kinetic data were fit to the appropriate rate equations by GraphPad Prism 7.0.

Confirmation of Covalent Modification of EP by LC-MS. The recombinant light chain of bovine EP (residues 801-1035) was studied by LC-MS to explore covalent modification of EP. Samples for LC-MS study were mixtures of $1 \mu \mathrm{M}$ EP and $10 \mu \mathrm{M}$ inhibitor in assay buffer, with a control sample that contained EP alone.

Intact protein LC-MS data were acquired on an Agilent 1290 UHPLC/6550 qTOF system. Two Phenomenex Aeris widepore XBC18 columns $(50 \times 2.1 \mathrm{~mm}, 3.6 \mu \mathrm{m}$; catalog number 00B-4482-AN) were used: one was maintained at $40^{\circ} \mathrm{C}$ and used with the normal sample injection, whereas the other column was maintained at $70^{\circ} \mathrm{C}$ and the sample injection was preceded with $20 \mu \mathrm{l}$ of $7 \mathrm{M}$ urea aqueous solution injected to create a denaturing condition. The mobile phases used were (A) water with $0.1 \%$ formic acid and (B) acetonitrile with $0.1 \%$ formic acid; the flow rate was $0.4 \mathrm{ml} / \mathrm{min}$. The LC linear gradient segments were as follows: 0 minutes, $5 \% \mathrm{~B} ; 4$ minutes, $99 \% \mathrm{~B}$; 5 minutes, $99 \%$ B; 5.5 minutes, $5 \%$ B; 6 minutes, $5 \%$ B. The qTOF was set at MS acquisition electrospray positive ion mode and calibrated to within $5 \mathrm{ppm}$ mass error. The MS acquisition range was from 300 to $2500 \mathrm{~m} / \mathrm{z}$ with a $2 \mathrm{~Hz}$ scanning rate. Intact protein molecular weight was deconvoluted from the raw data by using the Agilent MassHunter (version 4.0) Maximal Entropy deconvolution method. A ligand or ligand fragment covalently attached to EP shows an increase in molecular weight, and the $\mathrm{m} / \mathrm{z}$ measured with both columns is expected to be equivalent if the attachment is covalent and stable.

Inhibition Half-Life. Hydrolysis of EP-compound adduct was determined by measuring recovery of EP activity as a function of time. Samples were made by mixing $\mathrm{EP}(0.51 \mu \mathrm{M}$ final $)$ with an excess amount of compound $(23.3 \mu \mathrm{M}$ final) in the assay buffer and incubating at room temperature for 50 minutes. As a control, EP was incubated with DMSO. After incubation, $75 \mu \mathrm{l}$ of the sample was transferred to a pre-equilibrated Bio-Rad microspin column to remove free compound. Eluted EP-compound adduct was immediately diluted 100 -fold in reaction buffer by mixing with 300 and $600 \mu \mathrm{M}$ (final concentrations) of substrate. EP activity was observed to recover slowly with time. The time traces were fit to eq. 1 to derive the firstorder rate constant for reactivation. The final steady-state velocity was calculated from the control sample and set as a fixed parameter in the curve, fitting for the derivation of the dissociation rate constant of compound, $k_{\text {obs }}$. The half-life $\left(t_{1 / 2}\right)$ of EP recovery was derived from the value of $\ln (2) / k_{\text {obs }}$, i.e., $0.693 / k_{\text {obs }}$.

Protein Crystallography. Supercharged light-chain human EP (residues 785-1019) containing amino acid substitutions N6D, G21D, G22D, C112S, N142D, and K210E was expressed in $E$. coli, refolded from inclusion bodies, and purified as described previously (Simeonov et al., 2012). The protein at $10 \mathrm{mg} / \mathrm{ml}$ was crystallized from $22 \%(\mathrm{w} / \mathrm{v})$ PEG20,000, 0.1 M HEPES/NaOH ( $\mathrm{pH} 7.25$ ), by mixing $0.5 \mu \mathrm{l}$ of the protein with $0.5 \mu \mathrm{l}$ of the reservoir solution using hanging drop vapor diffusion at $18^{\circ} \mathrm{C}$. For complex formation, apo crystals were soaked at $10 \mathrm{mM}$ from a $100 \mathrm{mM}$ DMSO stock solution of compound 6 for 3 hours in reservoir solution at $\mathrm{pH} 6.5$ at $20^{\circ} \mathrm{C}$. Diffraction data were collected at the Diamond Light Source at beamline I02 (Didcot, Oxfordshire, UK) at a wavelength of $0.9159 \AA$. Data were processed with XDS and XSCALE (Kabsch, 2010) and CCP4 (Winn et al., 2011). The complex structure was solved by molecular replacement using the program MOLREP(Vagin and
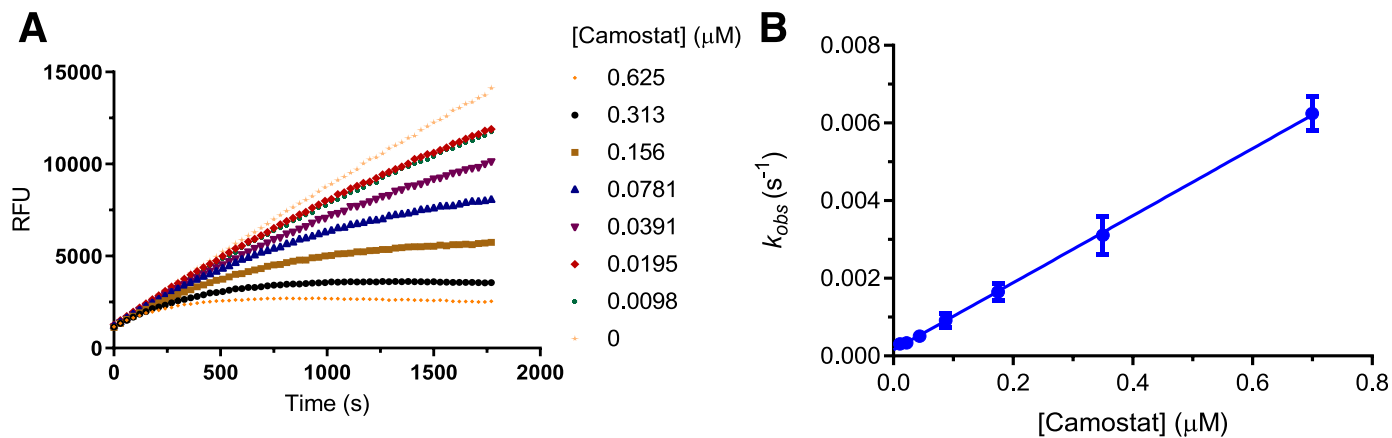

Fig. 3. Inhibition of EP by camostat. (A) Time-dependent inhibition of EP by camostat. Inhibition was determined in an assay using $300 \mu \mathrm{M}$ substrate and $1.25 \mathrm{nM}$ EP in the presence of various concentrations of camostat. First-order inactivation rate constants $\left(k_{o b s}\right)$ were derived from curve fitting to eq. 1 and then plotted against camostat concentration. (B) Camostat inhibition of EP was shown to follow a one-step mechanism, and the apparent compound potency $\left(k_{\text {inact }} / K_{\mathrm{I}}^{\text {app }}\right)$ was calculated to be $8.7 \times 10^{3} \mathrm{M}^{-1} \mathrm{~s}^{-1}$. RFU stands for the relative fluorescence units. 

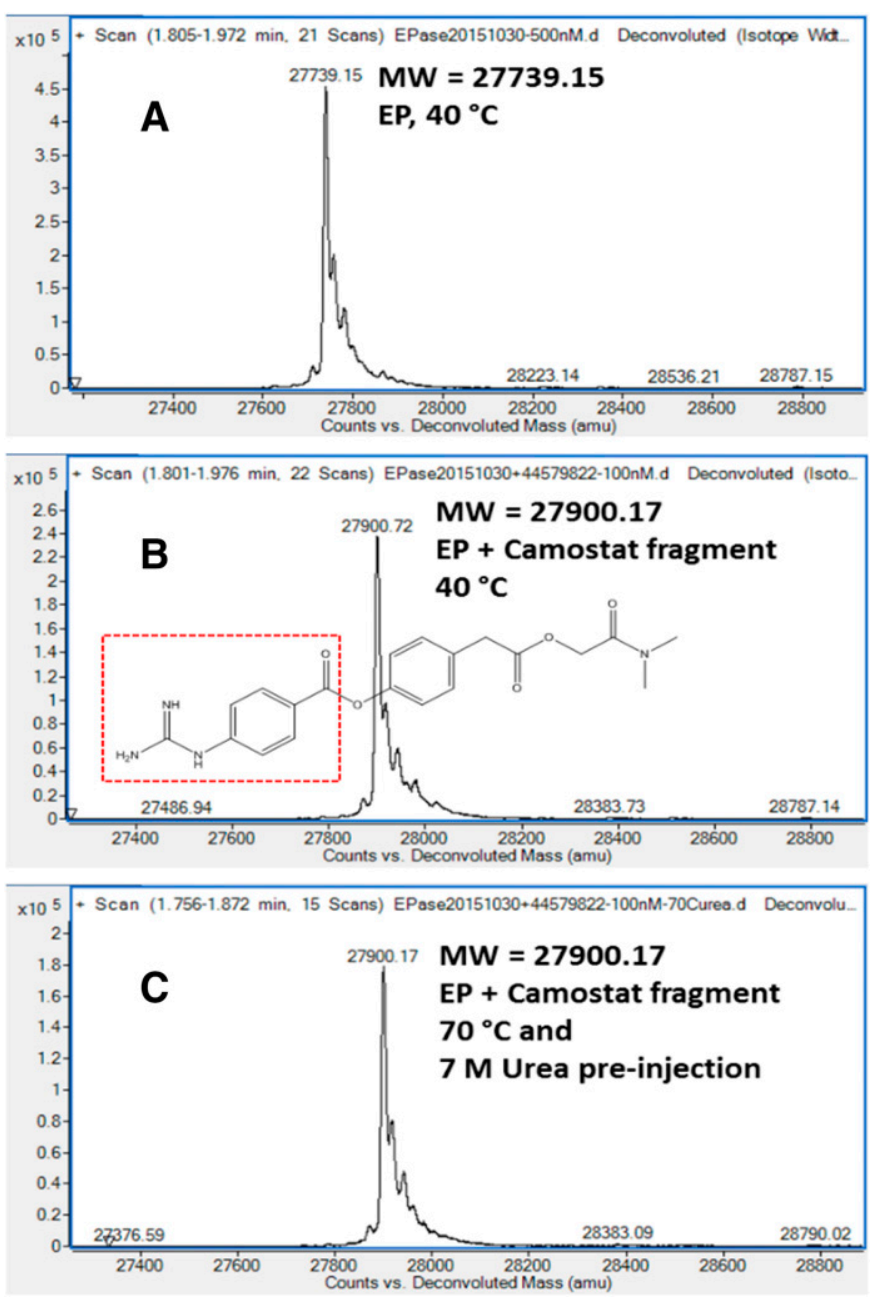

Fig. 4. High-resolution mass spectra of EP protein with and without camostat. (A) EP protein only; (B) EP protein after incubation with camostat, LC-MS run at $40^{\circ} \mathrm{C}$; (C) EP protein plus camostat, LC-MS run at $70^{\circ} \mathrm{C}$ after one injection of $7 \mathrm{M}$ urea. The addition of $161.6 \mathrm{Da}$ to $\mathrm{EP}$ after incubation with camostat was seen, and this addition corresponds to the camostat fragment in the dotted box (B), and the attachment is covalent. MW is the molecular weight.

Teplyakov, 2010) and refined with REFMAC5 (Murshudov et al., 2011). Model building was performed with COOT (Emsley et al., 2010).

Effect of Camostat on Food Intake, Body Weight, and Blood Glucose in Obese and Diabetic ob/ob Mice. Seven-week-old male leptin-deficient $o b / o b$ mice (Jax Laboratories, Bar Harbor, ME) were used. Animals were single-housed in a temperature-controlled room with a 12-hour light/dark cycle and allowed ad libitum access to water and powdered chow (modified Purina \#5008 irradiated chow with $2 \%$ maltose dextrin provided by Dyets, Inc.). Mice were randomized into five groups ( $n=8$ mice per group) based on baseline average body weights $(48.1 \pm 0.4 \mathrm{~g})$ and 5-hour fasted blood glucose levels [238.1 \pm $9.7 \mathrm{mg} / \mathrm{dl}$, measured with an AlphaTrak2 Glucometer (Abbott, Abbott Park, IL)]. After 4 days of recording baseline food intake and body weights, mice were fed powdered chow containing camostat $(\mathrm{w} / \mathrm{w})$ at $0.0,0.08,0.25,0.8 \mathrm{mg} / \mathrm{g}$ food (formulated by Dyets, Inc.) for 7 days. In the same study, a group of mice was pair-fed to the high-dose $(0.8 \mathrm{mg} / \mathrm{g}$ food) group, with these animals receiving the same amount of daily food as the camostat-treated group but fed a camostat-free diet.

Chemistry. ${ }^{1} \mathrm{H}$ NMR spectra were determined with a Bruker Biospin International AG-300 or AG-400 spectrometers at 300 or $400 \mathrm{MHz}$. Chemical shifts $(\delta)$ are reported in parts per million relative to residual chloroform (7.26 ppm), tetramethylsilane (TMS) (0 ppm),

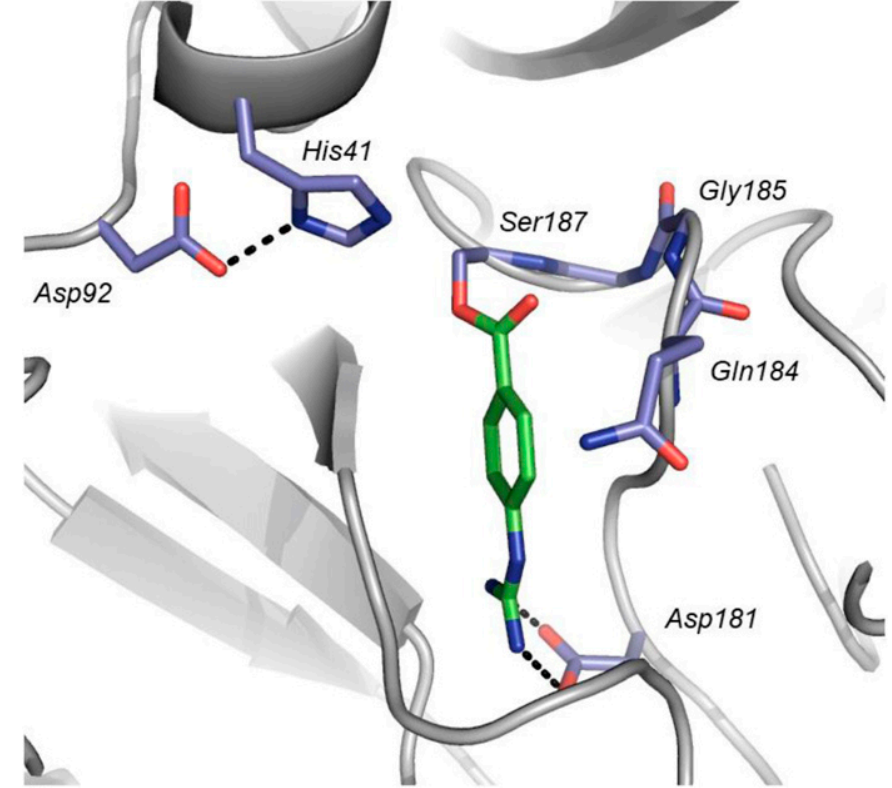

Fig. 5. Crystal structure of the EP-compound 6 reaction product adduct, resolved to $2.19 \AA$ (deposited at the PDB with ID code 6ZOV). The carboxymethylphenylguanidine is covalently bound to the catalytic nucleophile Ser187, with the guanidine moiety projecting down into S1 and forming a salt bridge with Asp181; the ester carbonyl does not project directly toward the oxyanion hole region but rather is directed away from the protein and toward bulk solvent. Residue numbering as in the published EP crystal structure (PDB ID 4DGJ). EP is shown as a gray ribbon, with selected side chains shown as purple color-by-atom sticks and the inhibitor moiety shown as green color-by-atom sticks. Selected atomatom contacts are highlighted with black dashed lines. PDB refers to the Protein Data Bank.

or $\mathrm{CD}_{3} \mathrm{OD}$ (4.87 ppm) as an internal reference with coupling constants (J) reported in hertz. The peak shapes are denoted as follows: singlet (s); doublet (d); triplet; quartet; multiplet (m); broad (br). Electrospray mass spectra were recorded in positive or negative mode on a Micromass Platform spectrometer. The purity of all compounds described here was determined by analytical LC-MS using a Shimadzu LCMS2110EV with analytical LC using Shiseido Capcell Pak C18 MGS3 column $(3.0 \times 50 \mathrm{~mm}, 3.5 \mu \mathrm{m}), 0.05 \%$ trifluoroacetic acid (TFA) in water as mobile phase A and $0.05 \%$ TFA in acetonitrile as mobile phase $\mathrm{B}$ at $1 \mathrm{ml} / \mathrm{min}$ flow, gradient from $10 \%$ to $100 \% \mathrm{~B}$ in 1.7 minutes, $100 \%$ B for 1.5 minutes, $100 \%-10 \%$ B in 0.13 minutes, monitored by UV absorption at $215 \mathrm{~nm}$ using photodiode array (PDA) and evaporative light scattering detector (ELSD). The purity of all compounds was found to be $>95 \%$. Thin-layer chromatography was performed on Merck PLC prescored plates $60 \mathrm{~F}_{254}$. Prep-HPLC conditions: (1\#waters 2767-5) column, SunFire Prep C18, 19*150 mm H Prep C-001(T) 1860025681951381641404 ; mobile phase, phase A: water with $0.05 \%$ TFA, phase B: $\mathrm{CH}_{3} \mathrm{CN}\left(20 \% \mathrm{CH}_{3} \mathrm{CN}\right.$ up to $50 \%$ in 8 minutes, up to $100 \%$ in 0.1 minutes, hold $100 \%$ in 1.9 minutes, down to $20 \%$ in 0.1 minutes, hold $20 \%$ in 1.9 minutes); detector, UV 220 and $254 \mathrm{~nm}$. Unless otherwise noted, reagents were obtained from commercial sources and were used without further purification.

Compound 11f (methyl 4-carbamimidamidobenzoate) was purchased from Enamine with $>95 \%$ purity. Compound 6 was prepared according to PCT International Application (1997), WO 9737969 A1 19971016

Preparation of 2-(3-Fluoro-4-((4-Guanidino Benzoyl) Oxy) Phenyl) Acetic Acid (11a). Into a 100-ml round-bottom flask was placed 2-(3-fluoro-4-hydroxyphenyl) acetic acid ( $3.0 \mathrm{~g}, 17.6 \mathrm{mmol}, 1.0$ $\mathrm{Eq})$ in dimethylformamide (DMF) $(30 \mathrm{ml}) ; \mathrm{NaH}$ (60\% in mineral oil, $776 \mathrm{mg}, 19.4 \mathrm{mmol}, 1.1 \mathrm{Eq}$ ) was added in portions at $0^{\circ} \mathrm{C}$. The mixture was stirred for 20 minutes and followed by the addition of benzyl 


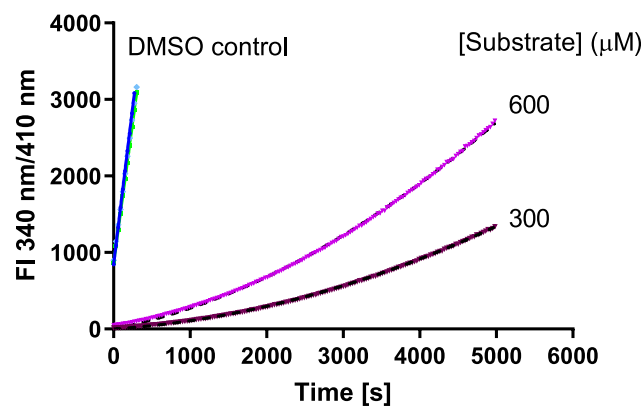

Fig. 6. Recovery of EP from camostat inhibition. EP activity was measured as a function of time in the presence of substrate at 300 and $600 \mu \mathrm{M}$, respectively, by a rapid dilution of covalently modified EP. The rate constant of acylated-EP hydrolysis was derived from data fitting analysis, and half-life of the EP recovery was calculated to be $14.3 \pm 3.8$ hours (average of $n=4$, duplicate at each concentration of substrate). FI stands for the fluorescence intensity.

bromide ( $4.51 \mathrm{~g}, 26.4 \mathrm{mmol}, 1.5 \mathrm{Eq}$ ) dropwise. The mixed solution was stirred for 4 hours at $25^{\circ} \mathrm{C}$. The reaction was then quenched by the addition of water. The resulting solution was extracted with ethyl acetate three times, and the organic layers were combined. The resulting solution was concentrated under vacuum. The residue was purified by CombiFlash system with silica gel using petroleum ether/ ethyl acetate $=4: 1$ solution. This afforded $1.9 \mathrm{~g}$ of benzyl 2-(3-fluoro-4hydroxyphenyl) acetate as white solid. MS (ESI): mass calculated for $\mathrm{C}_{15} \mathrm{H}_{13} \mathrm{FO}_{3} ; \mathrm{m} / \mathrm{z}, 260.3$; found, $259.0[\mathrm{M}-\mathrm{H}]$. Into a $250-\mathrm{ml}$ roundbottom flask was placed 4-guanidinobenzoic acid (1.32 g, $6.15 \mathrm{mmol}$, $2.0 \mathrm{Eq})$ in anhydrous pyridine $(26 \mathrm{ml})$, and the mixture solution was stirred for 5 minutes at room temperature. It was followed by the addition of benzyl 2-(3-fluoro-4-hydroxy phenyl) acetate ( $800 \mathrm{mg}, 3.07$ $\mathrm{mmol}, 1.0 \mathrm{Eq})$ and 4-methylbenzenesulfonic acid (106 mg, $0.62 \mathrm{mmol}$, $0.2 \mathrm{Eq}$ ). After 15 minutes, a solution of dicyclohexylmethanediimine $(1.90 \mathrm{~g}, 9.22 \mathrm{mmol}, 3.0 \mathrm{Eq})$ in dry DMF $(13 \mathrm{ml})$ was added at once, and the mixture was stirred at room temperature for 15 hours. The precipitated solid was filtered and washed with water $(20 \mathrm{ml})$. The resulting solution was extracted with ethyl acetate, and the organic layers were combined. The resulting solution was concentrated under vacuum. The residue was purified by a CombiFlash system with silica gel using dichloromethane $(\mathrm{DCM}) / \mathrm{MeOH}=5: 1$ solution. This afforded $800 \mathrm{mg}$ of 4-(2-(benzyloxy)-2-oxoethyl)-2fluorophenyl 4-guanidino benzoate as white solid. MS (ESI): mass calculated for $\mathrm{C}_{23} \mathrm{H}_{20} \mathrm{FN}_{3} \mathrm{O}_{4} ; \mathrm{m} / \mathrm{z}, 421.4$; found, $422.0[\mathrm{M}+\mathrm{H}]^{+}$.

Into a 250-ml round-bottom flask charged and maintained with an inert atmosphere of nitrogen was placed 4-(2-(benzyloxy)-2-oxoethyl)2-fluorophenyl 4-guanidino benzoate $(200 \mathrm{mg}, 0.48 \mathrm{mmol}, 1.0 \mathrm{Eq})$, $\mathrm{MeOH}(10 \mathrm{ml}), 5 \%$ palladium on carbon $(\mathrm{Pd} / \mathrm{C})(60 \mathrm{mg}) . \mathrm{H}_{2}$ was introduced into the mixture at 1 atmosphere. The mixture solution was stirred for 2 hours at $25^{\circ} \mathrm{C}$. The resulting mixture was filtered through a pad of Celite. The filtrate was concentrated under vacuum and recrystallized from the mixture of methanol and dichloromethane, which afforded $87.3 \mathrm{mg}$ (95\% yield) of 2-(3-fluoro-4-(4-guanidinobenzoyloxy) phenyl) acetic acid as white solid. MS (ESI): mass calculated for $\mathrm{C}_{16} \mathrm{H}_{14} \mathrm{FN}_{3} \mathrm{O}_{4} ; \mathrm{m} / \mathrm{z}, 331.3$; found, $331.9[\mathrm{M}+\mathrm{H}]^{+} .{ }^{1} \mathrm{H}$ NMR $(300$ $\left.\mathrm{MHz}, \mathrm{CD}_{3} \mathrm{OD}\right) \delta=8.29(\mathrm{~d}, J=2.1 \mathrm{~Hz}, 2 \mathrm{H}), 7.50(\mathrm{~d}, J=2.1 \mathrm{~Hz}, 2 \mathrm{H})$, $7.27-7.30(\mathrm{~m}, 2 \mathrm{H}), 7.20-7.25(\mathrm{~m}, 1 \mathrm{H}), 3.69(\mathrm{~s}, 2 \mathrm{H})$.

2-(4-((2-Chloro-4-Guanidinobenzoyl) Oxy) Phenyl) Acetic Acid (7). Analogous synthesis to 11a. Mass spectrum (ESI): mass calculated for $\mathrm{C}_{16} \mathrm{H}_{14} \mathrm{ClN}_{3} \mathrm{O}_{4}, 347.7$, found $348.0[\mathrm{M}+\mathrm{H}]^{+}$. ${ }^{1} \mathrm{H}$ NMR $\left(300 \mathrm{MHz}, \mathrm{DMSO}-d_{6}\right) \delta=8.10(\mathrm{~d}, J=8.4 \mathrm{~Hz}, 1 \mathrm{H}), 7.64-8.03(\mathrm{~m}, 2 \mathrm{H})$, 7.35-7.51 (m, 3H), 7.22-7.30 (m, 1H), 7.10-7.21 (m, $2 \mathrm{H}), 3.56(\mathrm{~s}, 2 \mathrm{H})$.

2-(4-(5-Guanidinopicolinoyl) Oxy) Phenyl) Acetic Acid (8). Analogous synthesis to 11a. MS (ESI): mass calculated for $\mathrm{C}_{15} \mathrm{H}_{14} \mathrm{~N}_{4} \mathrm{O}_{4} ; \mathrm{m} / \mathrm{z}, 314.3$; found, $315.3[\mathrm{M}+\mathrm{H}]^{+}$. ${ }^{1} \mathrm{H}$ NMR $(400 \mathrm{MHz}$, $\left.\mathrm{CD}_{3} \mathrm{OD}\right) \delta=7.05(\mathrm{~s}, 1 \mathrm{H}), 6.72(\mathrm{~d}, J=6.5 \mathrm{~Hz}, 1 \mathrm{H}), 6.29(\mathrm{~d}, J=7.0 \mathrm{~Hz}$, $1 \mathrm{H}), 5.72(\mathrm{~d}, J=8.1 \mathrm{~Hz}, 2 \mathrm{H}), 5.55(\mathrm{~d}, J=7.9 \mathrm{~Hz}, 2 \mathrm{H}), 1.98(\mathrm{~s}, 2 \mathrm{H})$.
TABLE 1

Data collection and processing statistics for the EP-compound 6 complex

\begin{tabular}{|c|c|}
\hline Ligand & Compound 6 \\
\hline $\mathrm{X}$-ray source & I02 (DLS) ${ }^{a}$ \\
\hline Wavelength $(\AA)$ & 0.9159 \\
\hline Detector & PILATUS 6M \\
\hline Temperature $(\mathrm{K})$ & 100 \\
\hline Space group & $\mathrm{P} 2_{1} 2_{1} 2_{1}$ \\
\hline Cell: a; b; c (A) & $52.93 ; 147.52 ; 147.52$ \\
\hline$\alpha ; \beta ; \gamma(\circ)$ & $90.0 ; 90.0 ; 90.0$ \\
\hline Resolution $(\AA)$ & $2.19(2.44-2.19)^{b}$ \\
\hline Unique reflections & $59,929(16,358)$ \\
\hline Multiplicity & $3.7(3.7)$ \\
\hline Completeness (\%) & $99.2(99.3)$ \\
\hline $\mathrm{R}_{\mathrm{sym}}(\%)^{c}$ & $10.7(48.7)$ \\
\hline $\mathrm{R}_{\text {meas }}(\%)^{d}$ & $12.6(57.1)$ \\
\hline Mean(I)/S.D. ${ }^{e}$ & $9.59(2.91)$ \\
\hline
\end{tabular}

${ }^{a}$ Diamond Light Source (DLS, Oxford, England).

${ }^{b}$ Values in parenthesis refer to the highest-resolution bin.

${ }^{c} R s y m=\frac{\sum_{h}^{n_{h}} \sum_{i} \hat{I}_{h}-I_{h, i} \mid}{\sum_{h}^{n_{h}} \sum_{i, i}}$ with $\hat{I}_{h}=\frac{1}{n_{h}} \sum_{i}^{n_{h}} I_{h, i}$, where $I_{h, i}$ is the intensity value of the $i$ th measurement of $h$

${ }^{d}$ Rmeas $=\frac{\sum_{h} \sqrt{n_{n}} \sum_{h}^{n_{h}-1} \sum_{i}^{n_{h}}\left|\hat{I}_{h}-I_{h, i}\right|}{\sum_{h}^{n_{h}} \sum_{i} I_{h, i}}$ with $\hat{I}_{h}=\frac{1}{n_{h}} \sum_{i}^{n_{h}} I_{h, i}$, where $I_{h, i}$ is the intensity value of

the $i$ th measurement of $h$.

${ }^{e}$ Calculated from independent reflections.

2-(4-(6-Guanidinonicotinoyl) Oxy) Phenyl) Acetic Acid (9). Analogous synthesis to 11a. MS (ESI): mass calculated for $\mathrm{C}_{15} \mathrm{H}_{14} \mathrm{~N}_{4} \mathrm{O}_{4} ; \mathrm{m} / \mathrm{z}, 314.3$; found, $315.3[\mathrm{M}+\mathrm{H}]^{+} .{ }^{1} \mathrm{H}$ NMR $(400 \mathrm{MHz}$, $\left.\mathrm{CD}_{3} \mathrm{OD}\right) \delta=7.58(\mathrm{~s}, 1 \mathrm{H}), 6.98(\mathrm{~m}, 1 \mathrm{H}), 5.85(\mathrm{~d}, J=8.0 \mathrm{~Hz}, 2 \mathrm{H}), 5.68(\mathrm{~d}$, $J=8.0 \mathrm{~Hz}, 2 \mathrm{H}), 5.60(\mathrm{~m}, 1 \mathrm{H}), 2.10(\mathrm{~s}, 2 \mathrm{H})$.

2-(3-Chloro-4-((4-Guanidinobenzoyl) Oxy) Phenyl) Acetic Acid (11b). Analogous synthesis to 11a. MS (ESI): mass calculated for $\mathrm{C}_{16} \mathrm{H}_{14} \mathrm{ClN}_{3} \mathrm{O}_{4} ; \mathrm{m} / \mathrm{z}, 347.8$; found, $348.9[\mathrm{M}+\mathrm{H}]^{+}$. ${ }^{1} \mathrm{H}$ NMR (300 $\left.\mathrm{MHz}, \mathrm{D}_{2} \mathrm{O}\right) \delta=8.10-8.13(\mathrm{~m}, 2 \mathrm{H}), 7.32-7.47(\mathrm{~m}, 3 \mathrm{H}), 7.12-7.19(\mathrm{~m}$, $2 \mathrm{H}), 3.54(\mathrm{~s}, 2 \mathrm{H})$.

TABLE 2

Refinement statistics for EP-compound 6 complex ${ }^{a}$

\begin{tabular}{|c|c|}
\hline Ligand & Compound 6 \\
\hline Resolution $(\AA)$ & $104.31-2.19$ \\
\hline Number of reflections (working/test) & $58,427 / 1502$ \\
\hline $\mathrm{R}_{\text {cryst }}(\%)$ & 22.6 \\
\hline $\mathrm{R}_{\text {free }}(\%)^{b}$ & 25.0 \\
\hline \multicolumn{2}{|l|}{ Total number of atoms: } \\
\hline Protein & 7462 \\
\hline Water & 453 \\
\hline Ligand & 48 \\
\hline Triethylene glycol & 10 \\
\hline Glycerol & 6 \\
\hline 1,2-Ethanediol & 24 \\
\hline \multicolumn{2}{|l|}{ Deviation from ideal geometry: ${ }^{c}$} \\
\hline Bond lengths $(\AA)$ & 0.011 \\
\hline Bond angles $\left({ }^{\circ}\right)$ & 1.56 \\
\hline Bonded B's $\left(\AA^{2}\right)^{d}$ & 1.6 \\
\hline \multicolumn{2}{|l|}{ Ramachandran plot: $^{e}$} \\
\hline Most favored regions (\%) & 87.2 \\
\hline Additional allowed regions (\%) & 12.2 \\
\hline Generously allowed regions (\%) & 0.6 \\
\hline Disallowed regions $(\%)$ & 0.0 \\
\hline
\end{tabular}

${ }^{a}$ Values as defined in REFMAC5, without sigma cutoff.

${ }^{b}$ Test set contains $2.5 \%$ of measured reflections.

${ }^{c}$ Root mean square deviations from geometric target values.

${ }^{d}$ Calculated with MOLEMAN

${ }^{e}$ Calculated with PROCHECK. 


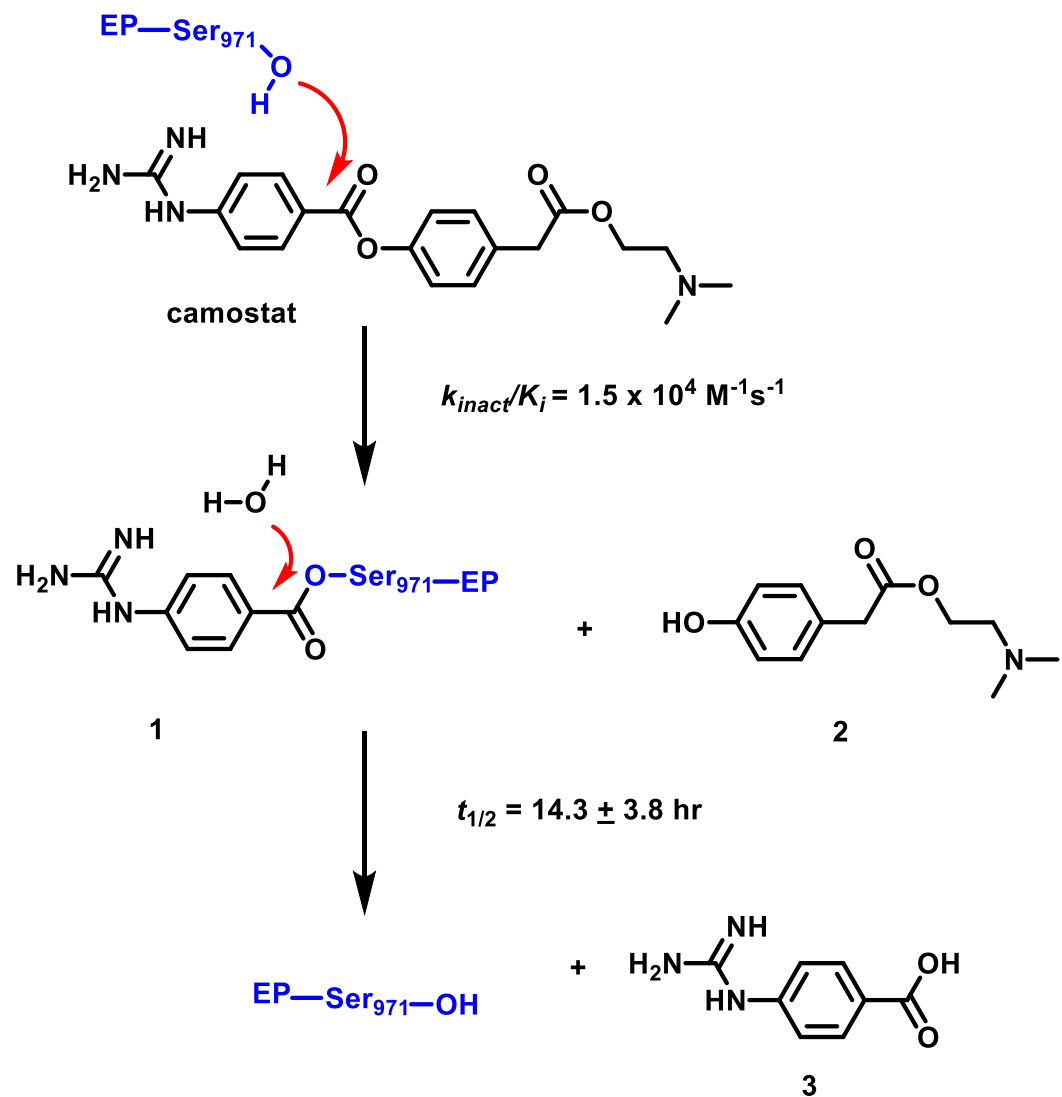

Fig. 7. Scheme of camostat inhibition of EP. Inhibition undergoes a covalent yet slowly reversible mechanism.

2-(3-Trifluoromethyl-4-((4-Guanidino Benzoyl) Oxy) Phenyl) Acetic Acid (11c). Analogous synthesis to 11a. MS (ESI): mass calculated for $\mathrm{C}_{17} \mathrm{H}_{14} \mathrm{~F}_{3} \mathrm{~N}_{3} \mathrm{O}_{4} ; \mathrm{m} / \mathrm{z}, 381.3$; found, $382.1[\mathrm{M}+\mathrm{H}]^{+} .{ }^{1} \mathrm{H}$ NMR $\left(400 \mathrm{MHz}, \mathrm{CD}_{3} \mathrm{OD}\right) \delta=8.24-8.26(\mathrm{~m}, 2 \mathrm{H}), 7.72(\mathrm{~s}, 1 \mathrm{H}), 7.66(\mathrm{~d}$, $J=8.8 \mathrm{~Hz}, 1 \mathrm{H}), 7.46-7.49(\mathrm{~m}, 2 \mathrm{H}), 7.42(\mathrm{~d}, J=8.4 \mathrm{~Hz}, 1 \mathrm{H}), 3.76(\mathrm{~s}, 2 \mathrm{H})$.

4-Chlorophenyl 4-Guanidinobenzoate (11d). Analogous synthesis to 11a. MS (ESI): mass calculated for $\mathrm{C}_{14} \mathrm{H}_{12} \mathrm{ClN}_{3} \mathrm{O}_{2} ; \mathrm{m} / \mathrm{z}, 289.7$; found, $290.1[\mathrm{M}+\mathrm{H}]^{+} .{ }^{1} \mathrm{H}$ NMR $\left(400 \mathrm{MHz}, \mathrm{CD}_{3} \mathrm{OD}\right) \delta=7.75(\mathrm{~d}, J=9.5$ $\mathrm{Hz}, 2 \mathrm{H}), 7.55(\mathrm{~d}, J=10.5 \mathrm{~Hz}, 2 \mathrm{H}), 7.48(\mathrm{~d}, J=8.5 \mathrm{~Hz}, 2 \mathrm{H}), 6.88(\mathrm{~d}, J=$ $9.5 \mathrm{~Hz}, 2 \mathrm{H})$.

2-((4-Guanidinobenzoyl) Oxy) Benzoic Acid (11e). Analogous synthesis to 11a. MS (ESI): mass calculated for $\mathrm{C}_{15} \mathrm{H}_{13} \mathrm{~N}_{3} \mathrm{O}_{4} ; \mathrm{m} / \mathrm{z}$, 299.3; found, $300.0[\mathrm{M}+\mathrm{H}]^{+} .{ }^{1} \mathrm{H}$ NMR $\left(400 \mathrm{MHz}, \mathrm{CD}_{3} \mathrm{OD}\right) \delta=8.31(\mathrm{~d}$, $J=7.8 \mathrm{~Hz}, 1 \mathrm{H}), 8.06(\mathrm{~m}, 1 \mathrm{H}), 7.99(\mathrm{~d}, J=8.1 \mathrm{~Hz}, 1 \mathrm{H}), 7.85(\mathrm{~m}, 1 \mathrm{H}), 7.80$ $(\mathrm{d}, J=9.0 \mathrm{~Hz}, 2 \mathrm{H}), 6.94(\mathrm{~d}, J=9.0 \mathrm{~Hz}, 2 \mathrm{H})$.

1,1,1,3,3,3-Hexafluoropropan-2-yl 4-Guanidinobenzoate (11g). Analogous synthesis to 11a. MS (ESI): mass calculated for
$\mathrm{C}_{11} \mathrm{H}_{9} \mathrm{~F}_{6} \mathrm{~N}_{3} \mathrm{O}_{2} ; \mathrm{m} / \mathrm{z}, 329.2$; found, $330.3[\mathrm{M}+\mathrm{H}]^{+} .{ }^{1} \mathrm{H}$ NMR $(400 \mathrm{MHz}$, DMSO $\left.-d_{6}\right) \delta=10.56(\mathrm{br}, \mathrm{s}, 1 \mathrm{H}), 8.11(\mathrm{~d}, J=7.5 \mathrm{~Hz}, 2 \mathrm{H}), 7.92(\mathrm{~s}, \mathrm{br}, 3 \mathrm{H})$, $7.48(\mathrm{~d}, J=7.5 \mathrm{~Hz}, 2 \mathrm{H}), 7.10(\mathrm{~m}, 1 \mathrm{H}) .{ }^{19} \mathrm{~F}$ NMR $\left(377 \mathrm{MHz}, \mathrm{DMSO}-d_{6}\right) \delta$ $=-72.5$.

Preparation of 2-(4-((4-Carbamimidoyl Phenoxy) Carbonyl) Phenyl) Acetic Acid (5). Into a 500-ml flask was added methyl 4iodobenzoate ( $10 \mathrm{~g}, 38.2 \mathrm{mmol}, 1 \mathrm{Eq})$, CuI (727 mg, $3.82 \mathrm{mmol}, 0.1 \mathrm{Eq})$, $\mathrm{Cs}_{2} \mathrm{CO}_{3}(37.3 \mathrm{~g}, 114.5 \mathrm{mmol}, 3 \mathrm{Eq})$, and 2-picolinic acid (931.9 mg, 7.63 mmol, $0.2 \mathrm{Eq})$. The flask was exchanged with $\mathrm{N}_{2}$, then dioxane $(100 \mathrm{ml})$ and tert-butyl 3-oxobutanoate $(12.3 \mathrm{ml}, 76.3 \mathrm{mmol}, 2 \mathrm{Eq})$ were added. The resulting mixture was stirred for 72 hours at $70^{\circ} \mathrm{C}$. The solvent was evaporated under reduced pressure, and then the mixture was diluted with ethyl acetate $(\mathrm{EtOAc})(150 \mathrm{ml})$. The mixture was washed with saturated $\mathrm{NH}_{4} \mathrm{Cl}(150 \mathrm{ml})$. The organic layer was dried over anhydrous $\mathrm{Na}_{2} \mathrm{SO}_{4}$ and concentrated under vacuum. The residue was purified with silica gel column chromatography (petroleum ether/ethyl acetate from 100:0 to 70:30) to afford methyl 4-(2-

TABLE 3

Inhibition of time-dependent inhibitors can only be accurately presented by $k_{\text {inact }} / K_{\mathrm{I}}$

\begin{tabular}{lll}
\hline Compound & Structure & $k_{\text {inact }} / K_{I}, \mathrm{M}^{-1} \mathrm{~s}^{-1}$ \\
\hline 4 & &
\end{tabular}


<smiles>N=C(N)Nc1ccc(C(=O)Oc2ccc(CC(=O)O)cc2)cc1</smiles>

$$
k_{\text {inact }} / K_{l}=5.87 \times 10^{3} M^{-1} s^{-1}
$$

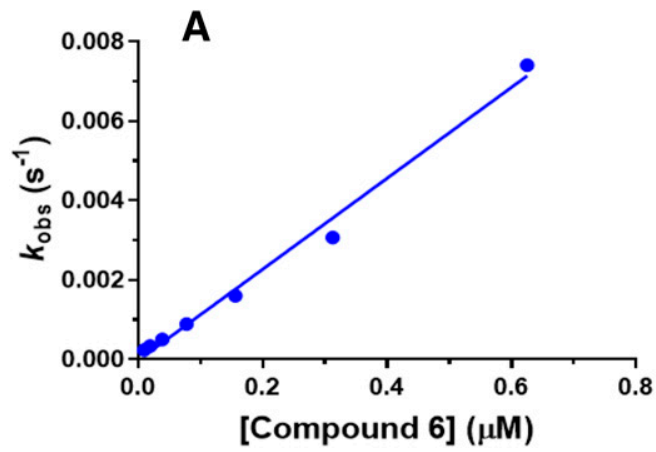

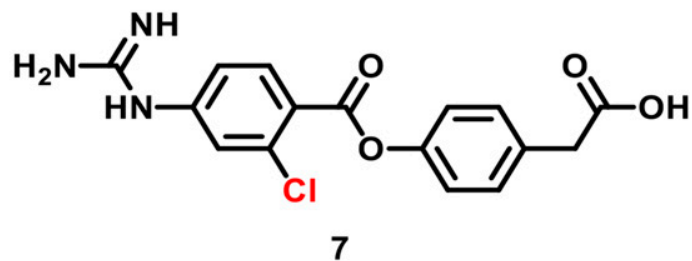

$$
\begin{aligned}
& k_{\text {inact }}=0.00362 \mathrm{~s}^{-1} \\
& K_{\mathrm{l}}=317 \mathrm{nM} \\
& k_{\text {inact }} / \mathrm{K}_{\mathrm{I}}=1.14 \times 10^{4} \mathrm{M}^{-1} \mathrm{~s}^{-1}
\end{aligned}
$$

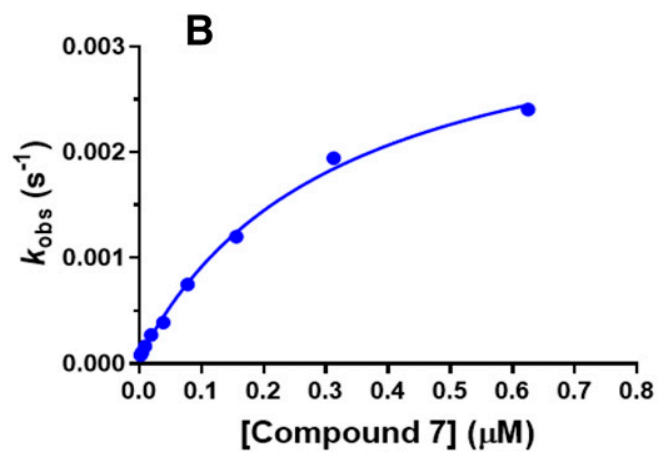

Fig. 8. Analogs of camostat have similar inhibition potencies but follow distinct inhibition mechanisms. (A) Linear dependence of the inactivation rate constant on compound concentration indicated a one-step inhibition mechanism for compound 6; (B) a hyperbolic curve of the plot indicated a two-step inhibition mechanism for compound $\mathbf{7}$.

tert-butoxy-2-oxoethyl) benzoate as yellow oil (4.7 $\mathrm{g}, 49 \%$ yield). MS (ESI): mass calculated for $\mathrm{C}_{14} \mathrm{H}_{18} \mathrm{O}_{4} ; \mathrm{m} / \mathrm{z}, 250.3$; found, $195.1[\mathrm{M}-t$-Bu $+\mathrm{H}]^{+}$.

To a stirred solution of methyl 4-(2-tert-butoxy-2-oxoethyl) benzoate $(1.6 \mathrm{~g}, 6.4 \mathrm{mmol}, 1 \mathrm{Eq})$ in $\mathrm{THF} / \mathrm{H}_{2} \mathrm{O}(\mathrm{v} / \mathrm{v}=2 / 1,30 \mathrm{ml})$ was added $\mathrm{LiOH} \cdot \mathrm{H}_{2} \mathrm{O}(402 \mathrm{mg}, 9.6 \mathrm{mmol}, 1.5 \mathrm{Eq})$ at $0{ }^{\circ} \mathrm{C}$. The mixture was stirred overnight while warming up to room temperature. The mixture was diluted with $\mathrm{H}_{2} \mathrm{O}$ and then extracted with DCM (100 ml) to remove unreacted starting material. The aqueous phase was acidified to $\mathrm{pH} 1-2$ with $1 \mathrm{~N} \mathrm{HCl}$ solution, extracted with EtOAc $(3 \times 100 \mathrm{ml})$. The combined organic phase was dried over $\mathrm{Na}_{2} \mathrm{SO}_{4}$, filtered, and concentrated under vacuum. The residue was purified with silica gel column chromatography (DCM/MeOH from 100:0 to 90:10) to afford 4-(2-tert-butoxy-2-oxoethyl) benzoic acid as white solid (650

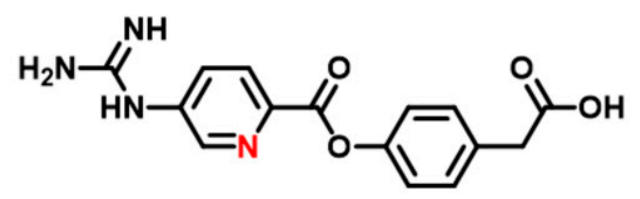

8

$$
k_{\text {inact }} / K_{l}=1.18 \times 10^{4} M^{-1} s^{-1}
$$

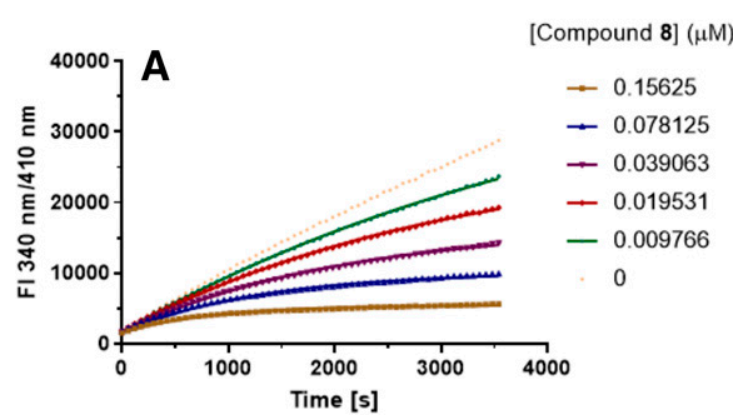

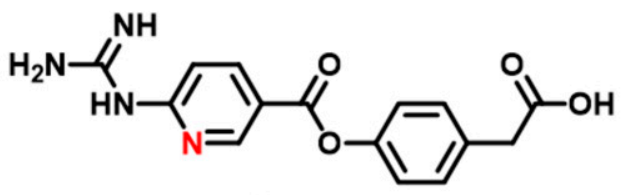

9

$$
\mathrm{IC}_{50}=0.031 \mu \mathrm{M}
$$

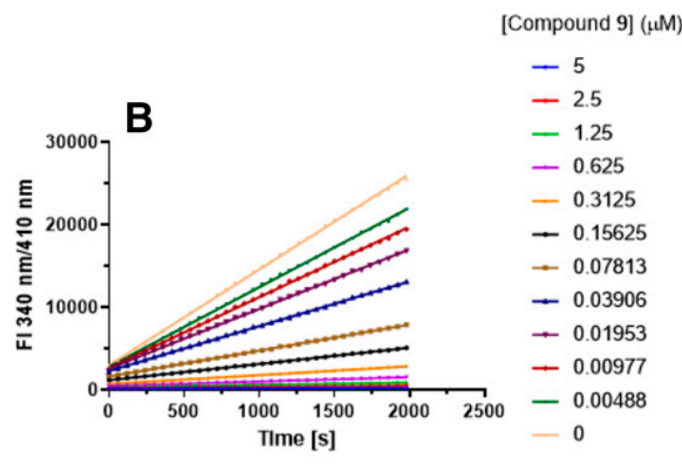

Fig. 9. A minor structural change of the inhibitor acyl moiety causes a change of the mechanism of inhibition from (A) thetime-dependent characteristics of compound $\mathbf{8}$ to (B) the reversible steady-state kinetics of compound $\mathbf{9}$ as displayed by the inhibition progress curves. FI stands for the fluorescence intensity. 


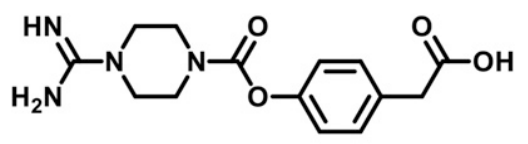

10

EP inhibition: $<5 \%$ at $50 \mu \mathrm{M}$

Fig. 10. Molecular structure of compound $\mathbf{1 0 .}$

mg, $43 \%$ yield). $\mathrm{MS}$ (ESI): mass calculated for $\mathrm{C}_{13} \mathrm{H}_{16} \mathrm{O}_{4} ; \mathrm{m} / \mathrm{z}, 236.3$; found, $235.0[\mathrm{M}-\mathrm{H}]^{-}$.

To a stirred solution of 4-(2-tert-butoxy-2-oxoethyl) benzoic acid (300 $\mathrm{mg}, 1.27 \mathrm{mmol}, 1 \mathrm{Eq}$ ) in pyridine was added 4-hydroxybenzimidamide (345 mg, $2.54 \mathrm{mmol}, 2 \mathrm{Eq}$ ), followed by dicyclohexylmethanediimine (393 mg, $1.91 \mathrm{mmol}, 1.5 \mathrm{Eq}$ ). The reaction was stirred at room temperature overnight. The solvent was evaporated under vacuum, and the residue was purified by silica gel column chromatography (70:30 EtOAc/petroleum ether, then flush from 0:100 to 15:85 MeOH/DCM mixed solution) to afford 4-carbamimidoylphenyl 4-(2-tert-butoxy-2oxoethyl)benzoate as white solid ( $350 \mathrm{mg}, 77.7 \%$ yield). MS (ESI): mass calculated for $\mathrm{C}_{20} \mathrm{H}_{22} \mathrm{~N}_{2} \mathrm{O}_{4} ; \mathrm{m} / \mathrm{z}, 354.4$; found, $355.2[\mathrm{M}+\mathrm{H}]^{+}$.

To a 100 -ml flask was added 4-carbamimidoylphenyl 4-(2-tertbutoxy-2-oxoethyl) benzoate $(350 \mathrm{mg}, 0.99 \mathrm{mmol})$ and $\mathrm{HCl}(4 \mathrm{M}$ in dioxane, $15 \mathrm{ml}$ ), and the mixture was stirred overnight at room temperature. The solvent was evaporated under vacuum, and the solid was recrystallized from cold ether to afford 2-(4-(4-carbamimidoylphenoxy) carbonyl) phenyl) acetic acid as white solid $(125.1 \mathrm{mg}$, $36.8 \%$ yield). $\mathrm{MS}$ (ESI): mass calculated for $\mathrm{C}_{16} \mathrm{H}_{14} \mathrm{~N}_{2} \mathrm{O}_{4} ; \mathrm{m} / \mathrm{z}, 298.3$; found, $299.1[\mathrm{M}+\mathrm{H}]^{+} .{ }^{1} \mathrm{H} \mathrm{NMR}\left(300 \mathrm{MHz}, \mathrm{CD}_{3} \mathrm{OD}\right) \delta=8.16(\mathrm{~d}, J=8.4$ $\mathrm{Hz}, 2 \mathrm{H}), 7.92(\mathrm{~d}, J=8.7 \mathrm{~Hz}, 2 \mathrm{H}), 7.45-7.55(\mathrm{~m}, 4 \mathrm{H}), 3.77(\mathrm{~s}, 2 \mathrm{H})$.

4-Carbamimidoyl-2-Fluorophenyl Benzoate (4). Analogous synthesis to 5. Mass spectrum (ESI, $\mathrm{m} / \mathrm{z}$ ): mass calculated for $\mathrm{C}_{14} \mathrm{H}_{11} \mathrm{FN}_{2} \mathrm{O}_{2}, \mathrm{~m} / \mathrm{z}, 258.3$; found, $259.1[\mathrm{M}+\mathrm{H}]^{+}$. ${ }^{1} \mathrm{H}$ NMR $(300 \mathrm{MHz}$, $\left.\mathrm{CD}_{3} \mathrm{OD}\right) \delta=8.21(\mathrm{~d}, J=7.5 \mathrm{~Hz}, 2 \mathrm{H}), 7.74-7.88(\mathrm{~m}, 3 \mathrm{H}), 7.46-7.68(\mathrm{~m}, 3 \mathrm{H})$.

Preparation of 2-(4-(4-Carbamimidoyl Piperazine-1-Carbonyl) Oxy) Phenyl) Acetic Acid (10). To a solution of benzyl 2(4-hydroxy phenyl) acetate ( $1 \mathrm{~g}, 4.13 \mathrm{mmol}, 1.0 \mathrm{Eq})$ and 4-nitrophenyl carbonochloridate $(874 \mathrm{mg}, 4.33 \mathrm{mmol}, 1.05 \mathrm{Eq})$ in DCM $(50 \mathrm{ml})$ was added triethylamine $(1.25 \mathrm{~g}, 12.4 \mathrm{mmol}, 3.0 \mathrm{Eq})$ at $0^{\circ} \mathrm{C}$. The mixture was warmed to room temperature and stirred for 1 hour. Then, tert-butyl piperidin-4-ylcarbamate $(1.24 \mathrm{~g}, 6.2 \mathrm{mmol}, 1.5 \mathrm{Eq})$ was added into the mixture. The solution was stirred for 2 hours at room temperature. The reaction was then quenched by the addition of water. The resulting solution was extracted with DCM, and the organic layers were combined. The resulting mixture was concentrated under vacuum. The residue was purified with silica gel column chromatography (petroleum ether/EtOAc 2:1) to afford $1.2 \mathrm{~g}$ of 1-(4-(2(benzyloxy)-2-oxoethyl) phenyl) 4-tert-butyl piperazine-1,4-dicarboxylate as white solid. Mass spectrum (ESI, m/z): mass calculated for $\mathrm{C}_{25} \mathrm{H}_{30} \mathrm{~N}_{2} \mathrm{O}_{6}, \mathrm{~m} / \mathrm{z}, 454.5$; found, $477.3[\mathrm{M}+\mathrm{Na}]^{+}$.

Into a 100-ml flask was added 1-(4-(2-(benzyloxy)-2-oxoethyl) phenyl) 4-tert-butyl piperazine-1,4-dicarboxylate (1.2 g, $2.64 \mathrm{mmol}, 1.0 \mathrm{Eq})$ and $20 \mathrm{ml}$ of $10 \%$ TFA solution in DCM. The mixture was stirred overnight at room temperature. The mixture was concentrated in vacuum to afford 4-(2-(benzyloxy)-2-oxoethyl) phenyl piperazine-1-carboxylate (862 mg, 69.7\% yield) as brown oil. Mass spectrum (ESI, m/z): mass calculated for $\mathrm{C}_{20} \mathrm{H}_{22} \mathrm{~N}_{2} \mathrm{O}_{4}, \mathrm{~m} / \mathrm{z}, 354.4$; found, $355.1[\mathrm{M}+\mathrm{H}]^{+}$.

Into a 250-ml flask was added 4-(2-(benzyloxy)-2-oxoethyl)phenyl piperazine-1-carboxylate $(620 \mathrm{mg}, 1.75 \mathrm{mmol}, 1 \mathrm{Eq})$, acetonitrile $(\mathrm{MeCN})(20 \mathrm{ml})$, and $\mathrm{N}, \mathrm{N}$-diisopropylethylamine (DIPEA) $(1.53 \mathrm{ml}$, $8.75 \mathrm{mmol}, 5 \mathrm{Eq}$ ), followed by $1 \mathrm{H}$-pyrazole-1-carboximidamide hydrochloride ( $308 \mathrm{mg}, 2.1 \mathrm{mmol}, 1.2 \mathrm{Eq}$ ). The mixture was stirred at room temperature overnight. The solvent was evaporated in vacuum, and the residue was dissolved in EtOAc $(100 \mathrm{ml})$ and then washed with $2 \mathrm{~N}$ $\mathrm{HCl}(100 \mathrm{ml})$. The organic layer was dried over $\mathrm{Na}_{2} \mathrm{SO}_{4}$, filtered, and concentrated in vacuum. The residue was purified with silica gel column

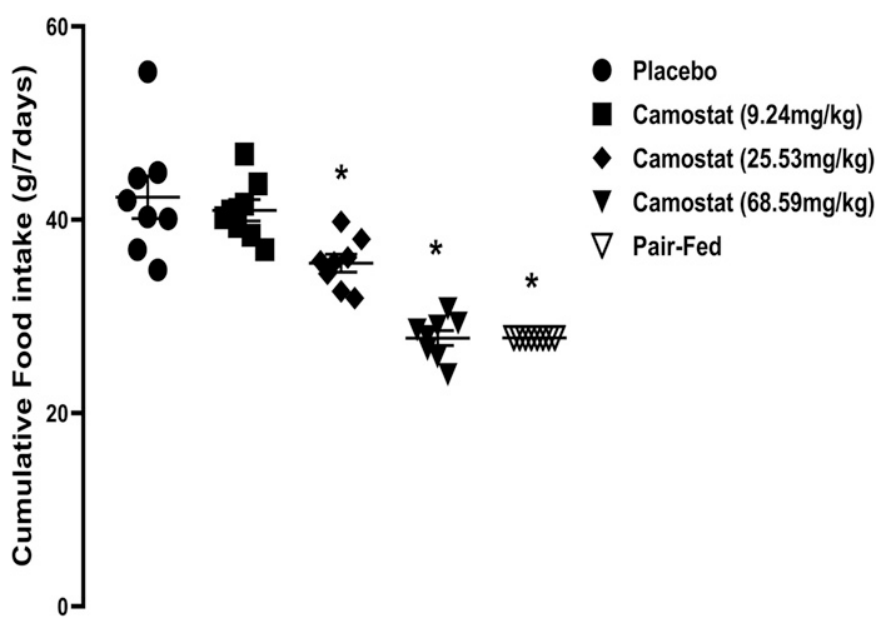

Fig. 11. Effects of 7 days of treatment with camostat given in feed on cumulative food intake in $o b / o b$ mice. Data are expressed as means \pm S.E.M. ( $n=8$ per group). ${ }^{*} P<0.05$ vs. placebo by one-way ANOVA followed by Dunnett's multiple comparisons test using Prism Graph Pad 7 software.

chromatography (MeOH/DCM from 0:100 to 15:85) to afford 4-(2(benzyloxy)-2-oxoethyl) phenyl 4-carbamimidoylpiperazine-1-carboxylate $(501 \mathrm{mg}, 72.2 \%$ yield) as white solid. Mass spectrum (ESI, m/z): mass calculated for $\mathrm{C}_{21} \mathrm{H}_{24} \mathrm{~N}_{4} \mathrm{O}_{4}, \mathrm{~m} / \mathrm{z}, 396.5$; found, $397.2[\mathrm{M}+\mathrm{H}]^{+}$.

To a 100-ml flask was added 4-(2-(benzyloxy)-2-oxoethyl) phenyl 4carbam imidoylpiperazine-1-carboxylate (494 mg, $1.25 \mathrm{mmol}$ ), $5 \% \mathrm{Pd} /$ $\mathrm{C}(200 \mathrm{mg})$ in $\mathrm{MeOH}(30 \mathrm{ml})$. The air in the flask was exchanged with 1 atmosphere of $\mathrm{H}_{2}$, and the mixture was stirred at room temperature under $\mathrm{H}_{2}$ overnight. $\mathrm{Pd} / \mathrm{C}$ was filtered through a pad of Celite, and the filtrate was evaporated under vacuum. The residue was recrystallized from $\mathrm{DMF} / \mathrm{HCl} /$ acetonitrile $(\mathrm{MeCN})$ mixed solution to afford 2-(4-(4carbamimidoylpiperazine-1-carbonyl oxy) phenyl) acetic acid as white solid (124.3 mg, 27.7\% yield). Mass spectrum (ESI, m/z): mass calculated for $\mathrm{C}_{14} \mathrm{H}_{18} \mathrm{~N}_{4} \mathrm{O}_{4}, \mathrm{~m} / \mathrm{z}, 306.3$; found, $307.1[\mathrm{M}+\mathrm{H}]^{+} .{ }^{1} \mathrm{H}$ NMR $\left(300 \mathrm{MHz}, \mathrm{D}_{2} \mathrm{O}\right) \delta=7.26(\mathrm{~d}, J=8.1 \mathrm{~Hz}, 2 \mathrm{H}), 7.03(\mathrm{~d}, J=8.4 \mathrm{~Hz}$, $2 \mathrm{H}), 3.76(\mathrm{br}, 2 \mathrm{H}), 3.66(\mathrm{~s}, 2 \mathrm{H}), 3.44-3.53(\mathrm{~m}, 6 \mathrm{H})$.

\section{Results}

EP cleaves peptide and protein substrates $\mathrm{N}$-terminal to $\mathrm{P} 1$ (Schechter and Berger, 1967) Lys or Arg residues and prefers Asp or Glu at the P2 position. Both the full-length and lightchain-only forms of EP recognize the activation peptide of trypsinogen, Gly-Asp-Asp-Asp-Asp-Lys $\left(\mathrm{GD}_{4} \mathrm{~K}\right)$ (Davie and Neurath, 1953; Davie and Neurath, 1955). An enzyme assay with the fluorogenic peptide $\mathrm{D}_{4} \mathrm{~K}-\mathrm{NA}$ as substrate was used to determine the protease activity of EP by following the fluorescence intensity of the cleavage product NA at excitation and emission wavelengths of 340 and $410 \mathrm{~nm}$, respectively (Grant and Hermon-Taylor, 1979). Characterization of the protease activity of full-length human EP was studied under steady-state conditions; the Michaelis-Menten constant $\mathrm{K}_{\mathrm{M}}$ and the apparent turnover number $k_{\text {cat }}$ were determined to be $412 \pm 22 \mu \mathrm{M}$ and $11.8 \pm 0.4 \mathrm{~s}^{-1}$, respectively (Fig. 2), with the catalytic efficiency of the enzyme therefore $2.86 \times 10^{4} \mathrm{M}^{-1} \mathrm{~s}^{-1}$. Kinetic characterization of the light-chain-only form of EP showed kinetic properties and catalytic efficiencies identical to those of the full-length enzyme (data not shown).

Inhibition of EP by Camostat. Camostat inhibits the enzymatic activity of EP in a time-dependent manner (Fig. 3A), with the observed inhibition following a one-step 


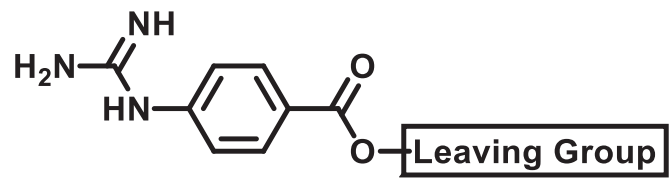

\begin{tabular}{|c|c|c|}
\hline Compound & Leaving Group & $k_{\text {inact }} / K_{I}, \mathrm{M}^{-1} \mathrm{~s}^{-1}$ \\
\hline 6 & & $1.02 \times 10^{4}$ \\
\hline $11 \mathrm{a}$ & & $1.68 \times 10^{4}$ \\
\hline $11 b$ & & $2.63 \times 10^{4}$ \\
\hline $11 \mathrm{c}$ & & $3.32 \times 10^{4}$ \\
\hline $11 d$ & & $9.66 \times 10^{3}$ \\
\hline $11 \mathrm{e}$ & & $4.46 \times 10^{2}$ \\
\hline $11 f$ & & $-6 \%$ at $10 \mu \mathrm{M}$ \\
\hline $11 \mathrm{~g}$ & & $4.89 \times 10^{2}$ \\
\hline
\end{tabular}

mechanism (Fig. 3B). The apparent inhibition potency $\left(k_{\text {inact }} t\right.$ $\mathrm{K}_{\mathrm{I}}^{\mathrm{app}}$ ) was determined to be $8.7 \times 10^{3} \mathrm{M}^{-1} \mathrm{~s}^{-1}$, and $k_{\text {inact }} / \mathrm{K}_{\mathrm{I}}$ was therefore $1.5 \times 10^{4} \mathrm{M}^{-1} \mathrm{~s}^{-1}$ following modification by the competing factor of $\left(1+[\mathrm{S}] / \mathrm{K}_{\mathrm{M}}\right)$, which is 1.728 for our assay conditions. The fact that the plot in Fig. 3B bisects the origin indicates that either the inhibition is irreversible or that it is reversible with a long residence time.

The results of an LC-MS study indicated covalent modification of EP by camostat. Preincubation of truncated EP (light chain of EP) with camostat showed an addition of $161.6 \mathrm{Da}$ to the protein, consistent with complex formation between the enzyme and the carboxyphenylguanidine moiety of camostat (Fig. 4; see also Fig. 5).

Interestingly, the enzymatic activity of EP could be recovered from fully inhibited EP after an overnight dialysis, consistent with slow release of active enzyme from the covalent adduct (data not shown). The rate of hydrolysis of acylated EP was determined by monitoring the recovery of enzyme activity over time (Fig. 6). The $t_{1 / 2}$ of the recovery of EP activity from fully inhibited enzyme was therefore calculated to be $14.3 \pm 3.8$ hours and was independent of the concentration of substrate used in the experiment.

Protein Crystallography. Initially, we used a publicly available crystal structure of a prostasin-camostat complex
(Spraggon et al., 2009) as a reference in advance of our own EP structural results. Prostasin, a trypsin-like serine protease, shows $39 \%$ sequence identity across the protease domain and $>70 \%$ sequence identity in the active site region (results not shown). Based on the extensive structural information available for phenylguanidine and related moieties occupying S1 of trypsin-like serine proteases, we were confident in predicting a similar binding mode for camostat with EP, including covalent labeling of the catalytic serine. This prediction was fully consistent with the results of our mechanistic studies, which are described in the preceding sections, and was subsequently supported by our own structural results (Tables 1 and 2).

Compound 6 is a close chemical analog of camostat but lacks the terminal dimethylaminoethyl ester moiety of the leaving group of the parent molecule. Furthermore, kinetic mechanistic studies indicate that compound $\mathbf{6}$ follows the same inhibitory mechanism as camostat (see Fig. 3 and Table 4; inhibition residence time of compound $\mathbf{6}$ is not shown here). Thus, we expect the structures of the reaction products of these two inhibitors with EP to be identical. The complex structure of the reaction product of the 3-hour soak of EP with compound 6 was determined to a resolution of $2.19 \AA$ (Fig. 5). This structure is fully consistent with the earlier structure of the prostasin-camostat complex mentioned above (Spraggon 
et al., 2009). In the EP complex, the carboxymethylphenylguanidine moiety occupies the $\mathrm{S} 1$ subsite, forming the expected salt bridge with the side chain of Asp181 at the base of this pocket. The side chain of the catalytic residue Ser187 has formed a covalent bond in the observed acyl-enzyme intermediate, unambiguously establishing the covalent nature of inhibition of EP by this class of inhibitors. The carbonyl oxygen of the adduct, positioned near to the oxyanion hole formed by Gly185 and Ser187, is directed away from the protein surface toward bulk solvent.

Mechanism of Inhibition. The scheme in Fig. 7 summarizes the mechanism of inhibition of EP by camostat. Camostat inhibits EP by forming a covalent adduct (1) between the nucleophile of EP active site serine residue and the acyl moiety of camostat. The acylated EP (1) is fully inactive and slowly hydrolyzed to release active EP with a $t_{1 / 2}$ of 14.3 hours.

SAR Generation of Camostat-Based Chemical Design. To target EP, exclusively expressed in the small intestine, a series of camostat analogs as biopharmaceutical classification system (BCS) class III structures with high solubility and poor permeability for targeting gut restriction were synthesized and characterized kinetically and mechanistically (Table 4). Removal of the dimethylaminoethyl group in camostat afforded zwitterionic structures, which were poorly permeable to minimize systemic exposure and maximize gastrointestinal tract exposure. Inhibition of EP by these compounds was consistently observed to be timedependent. Compound potencies were ranked by $k_{\text {inact }} / \mathrm{K}_{\mathrm{I}}$ values, as well as $\mathrm{K}_{\mathrm{i}}$ values (derived from the $I C_{50}$ based on initial velocities). Table 3 provides a telling example, with two analogs having equal potencies $\left(k_{\text {inact }} / \mathrm{K}_{\mathrm{I}}\right)$ showing a 5 -fold difference in the inhibition $\mathrm{K}_{\mathrm{i}}$. These data demonstrate that accurate SAR for time-dependent inhibitors can only be represented by the value of $k_{\text {inact }} / \mathrm{K}_{\mathrm{I}}$ derived from measuring the inactivation kinetics of the enzyme. Traditional $\mathrm{K}_{\mathrm{i}}$ (or $I C_{50}$ ) values alone could confuse or mislead the interpretation of SAR studies.

SAR of Medicinal Chemistry. It was observed that structural changes at the compound acyl moiety lead to a change in the inhibition mechanism. Compounds $\mathbf{6}$ and $\mathbf{7}$ are two close analogs, differing only at the ortho- position of the guanidine benzoyl ring. Both compounds inhibited EP in a time-dependent fashion with similar potencies $\left(k_{\text {inact }} / \mathrm{K}_{\mathrm{I}}\right)$ (Fig. 8). However, compound 6 inhibits EP in a one-step mechanism (Fig. 8A), whereas compound 7 shows a two-step mechanism (Fig. 8B). This is consistent with inhibition of EP by compound 6 being driven largely or completely by reactivity toward EP, whereas both the recognition (or binding) and reactivity components are significant contributors to inhibition by compound 7. Covalent inhibitors that follow a two-step mechanism that includes a significant or major recognition component are highly desired, as they are expected to show superior on-target selectivity and concomitant reduced in vivo off-target liabilities. Conversely, inhibitors driven largely or completely by reactivity are more likely to show a broader range of off-target activities (Cornish-Bowden, 2012; Copeland, 2013).

Compounds 8 and 9 are regioisomers bearing guanidinopicolinoyl-oxy moieties (Fig. 9), and this relatively minor structural variation in the acyl moiety resulted in a significant difference in the mechanism of inhibition. Linear reaction progress curves in the presence of compound $\mathbf{9}$ indicated

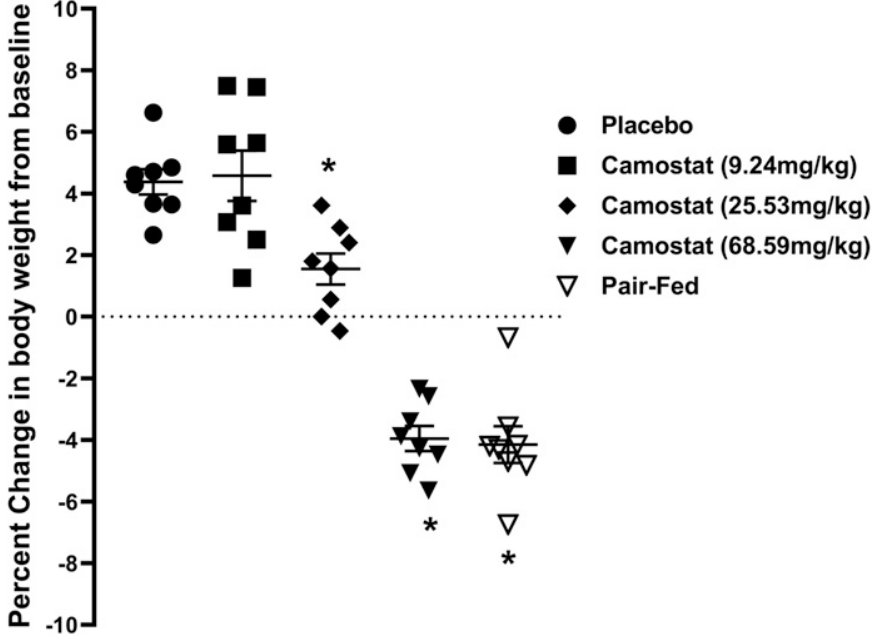

Fig. 12. Effects of 7 days of treatment with camostat given in feed on percent change in body weight from baseline in $o b / o b$ mice. Data are expressed as means \pm S.E.M. $(n=8$ per group). $* P<0.05$ vs. placebo by one-way ANOVA followed by Dunnett's multiple comparisons test using Prism Graph Pad 7 software.

a steady-state fast equilibrium reversible inhibition (Fig. 9B), whereas the nonlinear reaction progress curves reflected timedependent inhibition by compound 8 (Fig. 9A).

The acyl moiety plays a major role in modulating the compound potency, in addition to its role in regulating the inhibition mechanism. Compound 10 (Fig. 10) incorporates the same leaving group as compounds $\mathbf{8}$ and $\mathbf{9}$ (two potent inhibitors in Fig. 9), but replacement of the aromatic acyl moiety with a piperazine carbamate made the compound completely inactive toward $\mathrm{EP}(<5 \%$ inhibition was observed at $50 \mu \mathrm{M}$ compound).

The effect of the leaving group of the active esters was also extensively studied (Table 4). The data establish a clear dependence of inhibition potency on the leaving group, while the same one-step inhibition mechanism is conserved. Addition of a 3-F group on the phenyl acetic acid core of compound 6 slightly improved EP potency $\left(\mathbf{1 1 a}\right.$ vs. $6, k_{\text {inact }} / \mathrm{K}_{\mathrm{I}}, 1.68 \times 10^{4}$ vs. $1.02 \times$ $10^{4} \mathrm{M}^{-1} \mathrm{~s}^{-1}$ ). Moreover, analogs $11 \mathrm{~b}$ and 11c bearing the 3-Cl and $3-\mathrm{CF}_{3}$ substituents on the phenyl acetic acid core resulted in approximately 3 -fold increases in EP potency $\left(k_{\text {inact }} / \mathrm{K}_{\mathrm{I}}, 2.62\right.$ $\times 10^{4}$ for $11 \mathrm{~b} ; 3.32 \times 10^{4} \mathrm{M}^{-1} \mathrm{~s}^{-1}$ for $11 \mathrm{c}$ ), indicating electronic withdrawing groups may enhance the enzymatic reactivity of the active esters. Replacement of the acetic acid group with a $\mathrm{Cl}$ group on the phenyl ring was well tolerated (11d). In contrast, the para-substitutions between the acid and ester group were essential to EP potency. Compared with 6 bearing para-acetic acid group on the phenyl ring, compound 11e with orthocarboxylic acid substitution on the phenyl ring significantly attenuated $\mathrm{EP}$ potency to $k_{\text {inact }} / \mathrm{K}_{\mathrm{I}}, 4.46 \times 10^{2} \mathrm{M}^{-1} \mathrm{~s}^{-1}$. Removal of the phenyl ring abolished EP potency as shown in the methyl ester 11f. Incorporation of a nonaromatic electronic withdrawing group such as hexafluoropropyl in $\mathbf{1 1 g}$ recovered weak EP activity $\left(k_{\text {inact }} / \mathrm{K}_{\mathrm{I}}, 4.89 \times 10^{2} \mathrm{M}^{-1} \mathrm{~s}^{-1}\right)$ from the inactive $\mathbf{1 1 f}$.

Effect of Camostat on Food Intake and Body Weight in $\boldsymbol{o b} / \boldsymbol{o b}$ Mice. Leptin-deficient $o b / o b$ mice provide a model of obesity and hyperglycemia. The average doses of camostat $(0.08,0.25$ and $0.8 \mathrm{mg} / \mathrm{g}$ food) intake in feed over the 7 days of treatment were calculated as $9.24,25.5$, and $68.59 \mathrm{mg} / \mathrm{kg}$ per 


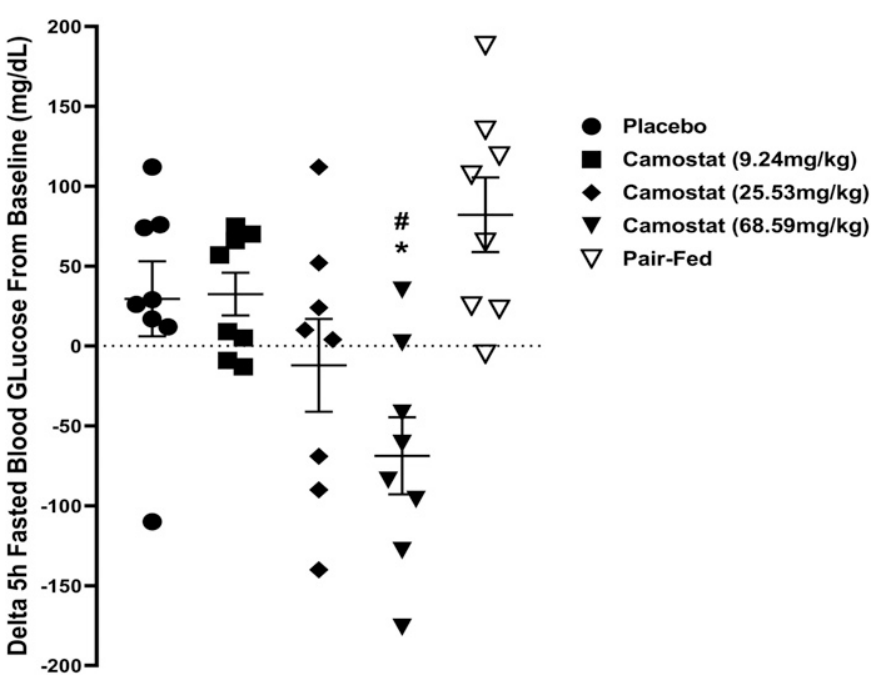

Fig. 13. Effects of 7 days of treatment with camostat given in feed on $\Delta 5$ hour fasted blood glucose in $o b / o b$ mice. Data are expressed as means \pm S.E.M. ( $n=8$ per group). $* P<0.05$ vs. placebo and ${ }^{\#} P<0.05$ vs. pair-fed group by one-way ANOVA followed by Dunnett's or Tukey's multiple comparisons test, respectively, using Prism Graph Pad 7 software.

day, respectively. Relative to the placebo control group, camostat reduced cumulative food intake by $-3.2 \%,-16.1 \%$, and $-34.4 \%$ at doses of $9.24,25.5$, and $68.59 \mathrm{mg} / \mathrm{kg}$ per day, respectively (see Fig. 11). Camostat reduced the percent change in body weight by $-2.8 \%$ and $-8.3 \%$ at doses of 25.5 and $68.59 \mathrm{mg} / \mathrm{kg}$ per day, respectively. There was no difference in weight loss between the camostat at high dose and pair-fed group, suggesting that reduced food intake is the primary mechanism for weight loss during the 7 days of treatment (Fig. 12). Baseline 5-hour fasted average blood glucose was $238.1 \pm 9.7 \mathrm{mg} / \mathrm{dl}(n=40)$. Treatment with camostat for 7 days reduced 5-hour fasted blood glucose by $15.6 \%$ and $36.9 \%$ at doses of 25.5 and $68.59 \mathrm{mg} / \mathrm{kg}$ per day, respectively. The 5 -hour fasted blood glucose was not reduced in the pair-fed group, despite the pair-fed group consuming similar amounts of food and showing weight loss similar to that seen for the camostattreated group, suggesting that the reduction in body weight or food intake may be not the reason for the improvement in glucose levels in camostat-treated animals (see Fig. 13).

\section{Discussion}

We discovered that camostat is a potent inhibitor of EP, with inhibition following a reversible covalent mechanism and showing a long inhibition half-life of 14.3 hours. A detailed inhibition kinetics study established that camostat inhibition of EP proceeded through a one-step mechanism, consistent with high reactivity toward EP in forming the covalent adduct. The initial binding complex between camostat and EP is weak and kinetically unstable. The mechanism of camostat inhibition of EP explains its poor selectivity among other serine proteases; to achieve high selectivity for EP and minimize in vivo off-target liabilities, an inhibitor with increased binding affinity for EP, therefore following a two-step inhibition mechanism, is preferable. Distinct from an irreversible covalent inhibitor, one advantage of developing a reversible covalent inhibitor drug could be in limiting the provocation of an immune response by avoiding the formation and accumulation of irreversibly modified protein. We have described the surprising discovery of EP inhibitors similar in structure to camostat but showing inhibition mechanisms distinct from that of camostat. We established that sustained inhibition of EP is required to attain a metabolic benefit in animal models (data not shown). In this light, knowledge of the detailed inhibition kinetics and mechanism is proving as important as inhibition potency in guiding our understanding of inhibitor SAR. We have outlined an in vitro biochemical and kinetic characterization framework to guide the discovery of a reversible covalent inhibitor of EP that could lead to new therapies for patients with obesity and diabetes.

\section{Acknowledgments}

We thank Janssen Research \& Development, LLC, for financial support. The crystal structure of the EP-compound $\mathbf{6}$ complex (PDB ID $6 \mathrm{ZOV}$ ) was determined at Proteros biostructures $\mathrm{GmbH}$ (Martinsried, Germany), and we appreciate the efforts and support of Georg Kempf, Klaus Maskos, and Stefan Steinbacher at Proteros.

\section{Authorship Contributions}

Participated in research design: Sun, X. Zhang, Zhu, Y. Zhang, Leonard, Lanter, Lenhard.

Conducted experiments: Sun, X. Zhang, Cummings, Albarazanji, Wu, Wang.

Performed data analysis: Sun, X. Zhang, Cummings, Albarazanji, Wu, Wang.

Wrote or contributed to the writing of the manuscript: Sun, $\mathrm{X}$. Zhang, Cummings, Albarazanji, Wu.

\section{References}

Bronze-da-Rocha E and Santos-Silva A (2018) Neutrophil elastase inhibitors and chronic kidney disease. Int J Biol Sci 14:1343-1360.

Copeland RA (2013) Evaluation of Enzyme Inhibitors in Drug Discovery, 2nd ed, John Wiley, New York.

Cornish-Bowden A (2012) Fundamentals of Enzyme Kinetics, 4th ed, Wiley-VCH Verlag, Berlin

Davie EW and Neurath H (1955) Identification of a peptide released during autocatalytic activation of trypsinogen. J Biol Chem 212:515-529.

Davie EW and Neurath H (1953) Identification of the peptide split from trypsinogen during autocatalytic activation. Biochim Biophys Acta 11:442.

Emsley P, Lohkamp B, Scott WG, and Cowtan K (2010) Features and development of Coot. Acta Crystallogr D Biol Crystallogr 66:486-501.

Grant DA and Hermon-Taylor J (1979) Hydrolysis of artificial substrates by enterokinase and trypsin and the development of a sensitive specific assay for enterokinase in serum. Biochim Biophys Acta 567:207-215.

Imamura T and Kitamoto Y (2003) Expression of enteropeptidase in differentiated enterocytes, goblet cells, and the tumor cells in human duodenum. Am J Physiol Gastrointest Liver Physiol 285:G1235-G1241.

Ito T, Otsuki M, Itoi T, Shimosegawa T, Funakoshi A, Shiratori K, Naruse S, and Kuroda Y, Research Committee of Intractable Diseases of the Pancreas (2007) Pancreatic diabetes in a follow-up survey of chronic pancreatitis in Japan. J Gastroenterol 42:291-297.

Kabsch W (2010) Integration, scaling, space-group assignment and post-refinement. Acta Crystallogr D Biol Crystallogr 66:133-144.

Kitagawa M and Hayakawa T (2007) Antiproteases and the pancreas: basic and clinical update. Introduction. JOP 8(4 Suppl):476-478.

Kitamoto Y, Veile RA, Donis-Keller H, and Sadler JE (1995) cDNA sequence and chromosomal localization of human enterokinase, the proteolytic activator of trypsinogen. Biochemistry 34:4562-4568.

Kitamoto Y, Yuan X, Wu Q, McCourt DW, and Sadler JE (1994) Enterokinase, the initiator of intestinal digestion, is a mosaic protease composed of a distinctive assortment of domains. Proc Natl Acad Sci USA 91:7588-7592.

Light A and Janska H (1989) Enterokinase (enteropeptidase): comparative aspects. Trends Biochem Sci 14:110-112.

Lu D, Fütterer K, Korolev S, Zheng X, Tan K, Waksman G, and Sadler JE (1999) Crystal structure of enteropeptidase light chain complexed with an analog of the trypsinogen activation peptide. J Mol Biol 292:361-373.

Murshudov GN, Skubák P, Lebedev AA, Pannu NS, Steiner RA, Nicholls RA, Winn MD, Long F, and Vagin AA (2011) REFMAC5 for the refinement of macromolecular crystal structures. Acta Crystallogr D Biol Crystallogr 67:355-367.

Ramsey ML, Nuttall J, and Hart PA; TACTIC Investigative Team (2019) A phase 1/2 trial to evaluate the pharmacokinetics, safety, and efficacy of NI-03 in patients with chronic pancreatitis: study protocol for a randomized controlled trial on the assessment of camostat treatment in chronic pancreatitis (TACTIC). Trials 20:501. Sasaki M, Miyahisa I, Itono S, Yashiro H, Hiyoshi H, Tsuchimori K, Hamagami KI, Moritoh Y, Watanabe M, Tohyama K, et al. (2019) Discovery and characterization of a small-molecule enteropeptidase inhibitor, SCO-792. Pharmacol Res Perspect 7: $\mathrm{e} 00517$. 
Schechter I and Berger A (1967) On the size of the active site in proteases. I. Papain. Biochem Biophys Res Commun 27:157-162.

Simeonov P, Zahn M, Sträter N, and Zuchner T (2012) Crystal structure of a supercharged variant of the human enteropeptidase light chain. Proteins 80:1907-1910. Spraggon G, Hornsby M, Shipway A, Tully DC, Bursulaya B, Danahay H, Harris JL, and Lesley SA (2009) Active site conformational changes of prostasin provide a new mechanism of protease regulation by divalent cations. Protein Sci 18:1081-1094.

Vagin A and Teplyakov A (2010) Molecular replacement with MOLREP. Acta Crystallogr D Biol Crystallogr 66:22-25.

Winn MD, Ballard CC, Cowtan KD, Dodson EJ, Emsley P, Evans PR, Keegan RM, Krissinel EB, Leslie AG, McCoy A, et al. (2011) Overview of the CCP4 suite and current developments. Acta Crystallogr D Biol Crystallogr 67:235-242.

Yashiro H, Hamagami K, Hiyoshi H, Sugama J, Tsuchimori K, Yamaguchi F, Moritoh Y, Sasaki M, Maekawa T, Yamada Y, et al. (2019) SCO-792, an enteropeptidase inhibitor, improves disease status of diabetes and obesity in mice. Diabetes Obes Metab 21:2228-2239.

Yuan X, Zheng X, Lu D, Rubin DC, Pung CY, and Sadler JE (1998) Structure of murine enterokinase (enteropeptidase) and expression in small intestine during development. Am J Physiol 274:G342-G349.
Zamolodchikova TS, Scherbakov IT, Khrennikov BN, and Svirshchevskaya EV (2013) Expression of duodenase-like protein in epitheliocytes of Brunner's glands in human duodenal mucosa. Biochemistry (Mosc) 78:954-957.

Zamolodchikova TS, Sokolova EA, Alexandrov SL, Mikhaleva II, Prudchenko IA, Morozov IA, Kononenko NV, Mirgorodskaya OA, Da U, Larionova NI, et al. (1997) Subcellular localization, substrate specificity and crystallization of duodenase, a potential activator of enteropeptidase. Eur J Biochem 249: $612-621$.

Zamolodchikova TS, Sokolova EA, Lu D, and Sadler JE (2000) Activation of recombinant proenteropeptidase by duodenase. FEBS Lett 466:295-299.

Zheng XL, Kitamoto Y, and Sadler JE (2009) Enteropeptidase, a type II transmembrane serine protease. Front Biosci (Elite Ed) 1:242-249.

Address correspondence to: Dr. Weimei Sun, Janssen Research \& Development, Welsh and McKean Roads, P. O. Box 776, Spring House, PA 19477. E-mail: wsun5@its.jnj.com 